LOCKNEED MARTIN

ORNL/ER-386

ENVIRONMENTAL

RESTORATION

PROGRAM

\section{Annual Report on Surveillance and Maintenance Activities at Oak Ridge National Laboratory, \\ Oak Ridge, Tennessee}

Fiscal Year 1996
MANAGED BY

LOCKHEED MARTIN ENERGY SYSTEMS, INC.

FOR THE UNITED STATES

DEPARTMENT OF ENERGY
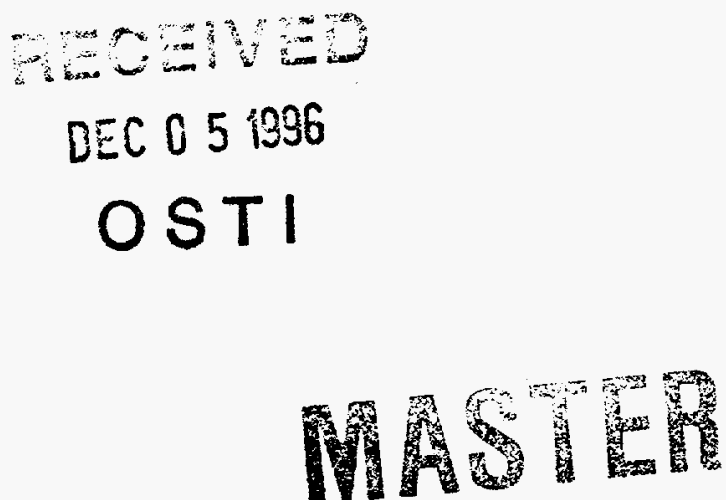

This document has been approved by the ORNL Technical Information Office for release to the public. Date:

422194 


\section{CDM Federal Programs Corporation and The S.M. Stoller Corporation}

contributed to the preparation of this document and should not be considered eligible contractors for its review. 


\section{DISCLAIMER}

This report was prepared as an account of work sponsored by an agency of the United States Government. Neither the United States Government nor any agency thereof, nor any of their employees, makes any warranty, express or implied, or assumes any legal liability or responsibility for the accuracy, completeness, or usefulness of any information, apparatus, product, or process disclosed, or represents that its use would not infringe privately owned rights. Reference herein to any specific commercial product, process, or service by trade name, trademark, manufacturer, or otherwise does not necessarily constitute or imply its endorsement, recommendation, or favoring by the United States Government or any agency thereof. The views and opinions of authors expressed herein do not necessarily state or reflect those of the United States Government or any agency thereof. 


\section{DISCLAIMER}

Portions of this document may be illegible in electronic image products. Images are produced from the best available original document. 
Energy Systems Environmental Restoration Program

\author{
Annual Report on Surveillance \\ and Maintenance Activities \\ at Oak Ridge National Laboratory, \\ Oak Ridge, Tennessee
}

Fiscal Year 1996

Date Issued—November 1996

\author{
Prepared by \\ - CDM Federal Programs Corporation \\ and \\ The S.M. Stoller Corporation \\ Oak Ridge, Tennessee \\ under subcontract 70M-SC914C
}

Prepared for the

U.S. Department of Energy

Office of Environmental Management

under budget and reporting codes EW 20 and EX 20

Environmental Management Activities at the

OAK RIDGE NATIONAL LABORATORY

Oak Ridge, Tennessee 37831-6285

managed by

LOCKHEED MARTIN ENERGY SYSTEMS, INC.

for the

U.S. DEPARTMENT OF ENERGY

under contract DE-AC05-84OR21400 


\section{PREFACE}

This Annual Report on Surveillance and Maintenance Activities at Oak Ridge National Laboratory, Oak Ridge, Tennessee: Fiscal Year 1996 (ORNL/ER-386) was prepared to communicate the Surveillance and Maintenance accomplishments of the Environmental Restoration Program during fiscal year 1996. This work was performed under Work Breakdown Structure element 1.4.12.6.1.14.05 (Activity Data Sheet 3314, "S\&M Program Integration"). Publication of this document meets the Life Cycle Baseline milestone date of November 30, 1996. This document provides the accomplishments for both the Remedial Action and Decontamination and Decommissioning Surveillance and Maintenance programs. 


\section{TABLE OF CONTENTS}

PREFACE

FIGURES

iv

ABBREVIATIONS $\ldots \ldots \ldots \ldots \ldots \ldots \ldots \ldots \ldots \ldots \ldots \ldots \ldots \ldots \ldots \ldots \ldots \ldots \ldots \ldots \ldots \ldots$

EXECUTIVE SUMMARY $\ldots \ldots \ldots \ldots \ldots \ldots \ldots \ldots \ldots \ldots \ldots \ldots \ldots \ldots \ldots \ldots \ldots \ldots$

1. INTRODUCTION $\ldots \ldots \ldots \ldots \ldots \ldots \ldots \ldots \ldots \ldots \ldots \ldots \ldots \ldots \ldots \ldots \ldots \ldots \ldots$

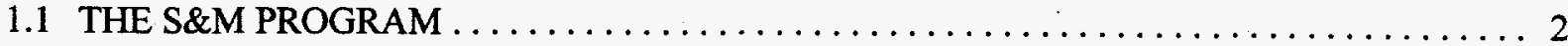

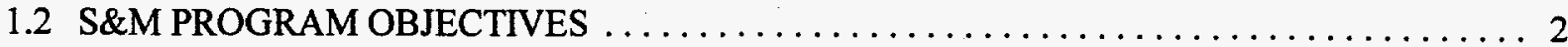

2. FY 1996 RA S\&M PROGRAM ACCOMPLISHMENTS $\ldots \ldots \ldots \ldots \ldots \ldots \ldots \ldots \ldots \ldots$

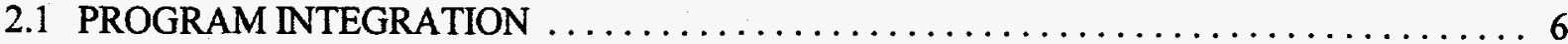

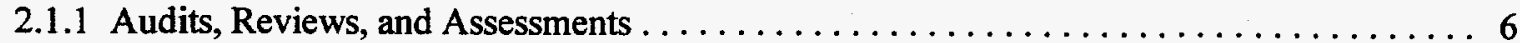

2.1.2 Plans, Reports, and Coordinating Documents $\ldots \ldots \ldots \ldots \ldots \ldots \ldots \ldots \ldots \ldots$

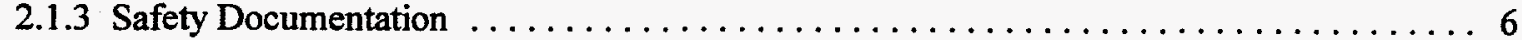

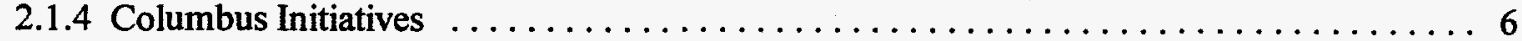

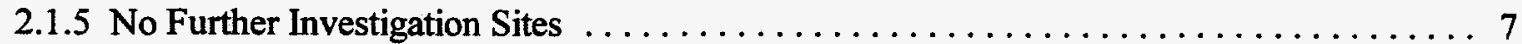

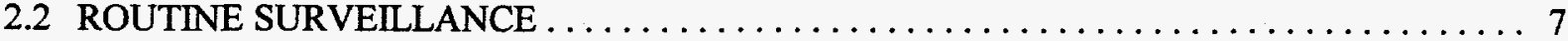

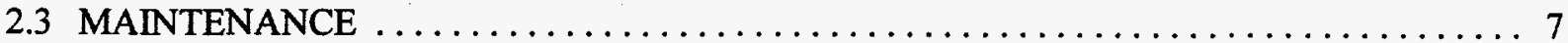

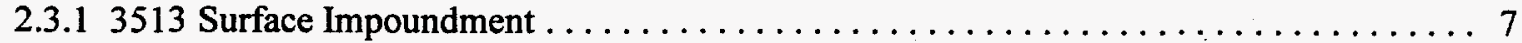

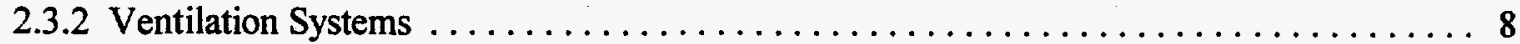

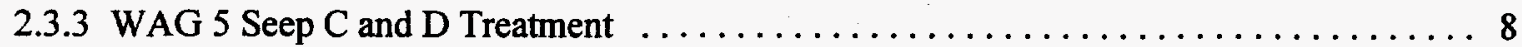

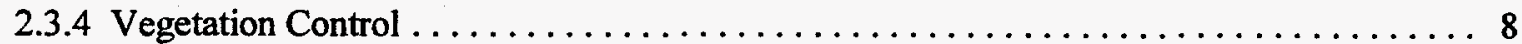

2.3.5 Subsidence Fills . . . . . . . . . . . . . . . . . . . . . . . . . . . 9

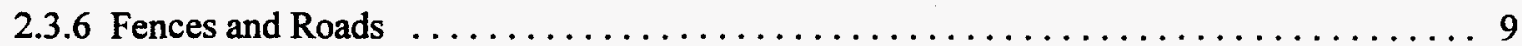

2.3.7 3001 Canal Clean-up . . . . . . . . . . . . . . . . . . . . . . . . . . . . . 9

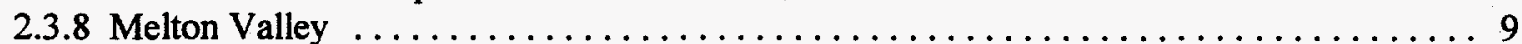

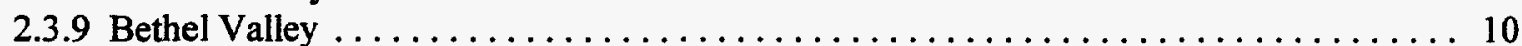

2.4 POST REMEDIATION MONITORING $\ldots \ldots \ldots \ldots \ldots \ldots \ldots \ldots \ldots \ldots \ldots \ldots \ldots \ldots$

3. FY 1996 D\&D S\&M PROGRAM ACCOMPLISHMENTS $\ldots \ldots \ldots \ldots \ldots \ldots \ldots \ldots \ldots \ldots 11$

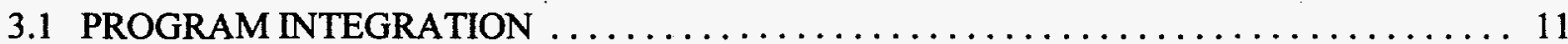

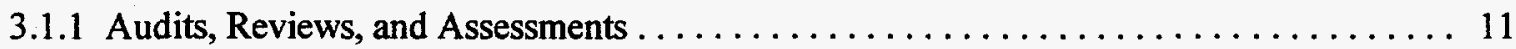

3.1.2 Plans, Reports, and Coordinating Documents $\ldots \ldots \ldots \ldots \ldots \ldots \ldots \ldots \ldots \ldots \ldots \ldots \ldots$

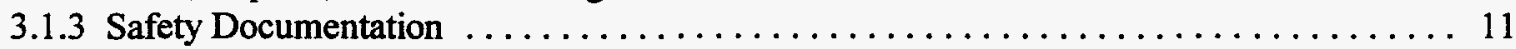

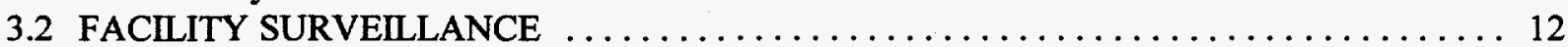

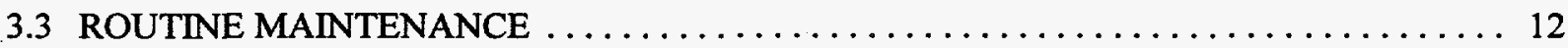

Appendix A ORNL SURVEILLANCE AND MAINTENANCE PROGRAM

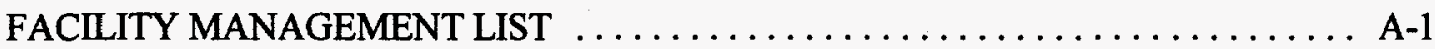

Appendix B SUMMARY OF INACTIVE LLW TANK LEVEL TRENDING ACTIVITIES . . . . . B B-1 


\section{FIGURES}

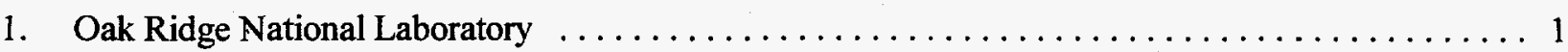

2. ORNL S\&M sites/facilities located in the main plant area $\ldots \ldots \ldots \ldots \ldots \ldots \ldots \ldots \ldots \ldots$

3. ORNL S\&M sites/facilities located in Melton Valley $\ldots \ldots \ldots \ldots \ldots \ldots \ldots \ldots \ldots \ldots \ldots$

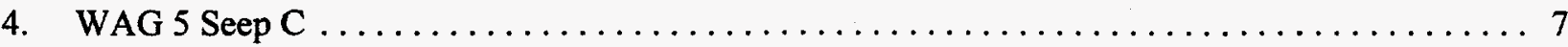

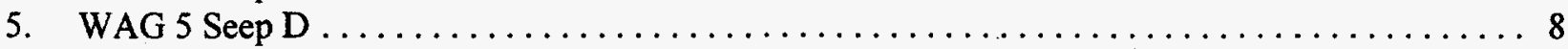

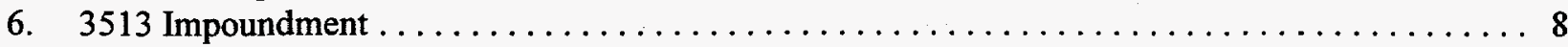

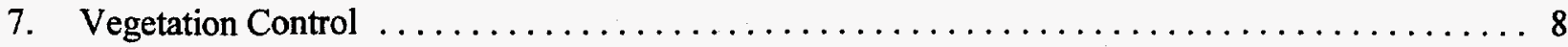

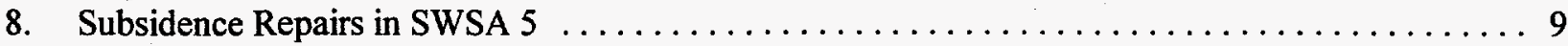

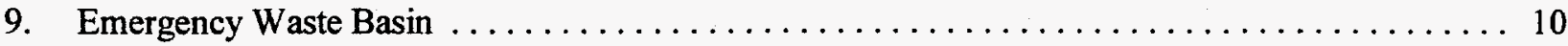

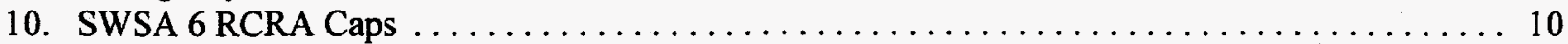

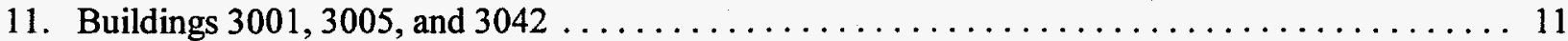

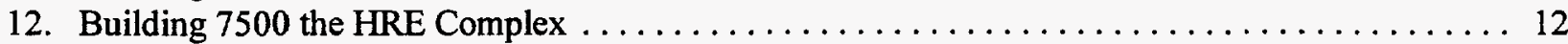

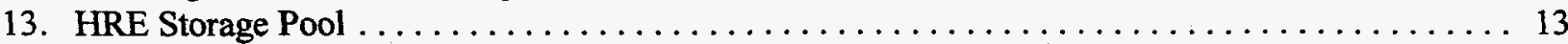




\section{ACRONYMS}

\begin{tabular}{|c|c|}
\hline ASA & Auditable Safety Analysis \\
\hline D\&D & decontamination and decommissioning \\
\hline DOE & U.S. Department of Energy \\
\hline ER & Environmental Restoration \\
\hline FAB & Facility Authorization Basis \\
\hline FFA & Federal Facilities Agreement \\
\hline FY & fiscal year \\
\hline HRE & Homogeneous Reactor Experiment \\
\hline ITO & Incentive Task Order \\
\hline LCD & Limited Conditions Document \\
\hline LLLW & liquid low-level waste \\
\hline MOA & memorandum of agreement \\
\hline OGR & Oak Ridge Graphite Reactor \\
\hline ORNL & Oak Ridge National Laboratory \\
\hline ORR & Oak Ridge Research Reactor \\
\hline PHS & Preliminary Hazard Screening \\
\hline PSET & Plant Safety Evaluation Team \\
\hline RA & remedial action \\
\hline RCRA & Resource Conservation and Recovery Act \\
\hline S\&M & surveillance and maintenance \\
\hline SWSA & solid waste storage area \\
\hline WAG & waste area grouping \\
\hline
\end{tabular}




\section{EXECUTIVE SUMMARY}

In fiscal year (FY) 1995, the sites and facilities from both the Remedial Action (RA) and Decontamination and Decommissioning (D\&D) programs were combined to form the Oak Ridge National Laboratory (ORNL) Environmental Restoration (ER) Surveillance and Maintenance (S\&M) Program. This combined program includes all ER-owned facilities (i.e., inactive liquid low-level waste storage tanks, impoundments, burial grounds, test sites, leak sites, contaminated soil, inactive reactor buildings, cooling towers, pump houses, evaporators, hot cells, wells and boreholes, and various research and development facilities). The establishment of a unified S\&M Program facilitates the management of the applicable areas or facilities following their operating life and until final disposition or site stabilization (whichever is deemed most appropriate based on environmental regulations and/or best management practices). The ORNL ER S\&M Program objectives are

- conducting facility assessments as necessary to define and maintain baseline facility conditions;

- implementing a graded and cost-effective surveillance and inspection process for RA and $D \& D$ facilities to ensure compliance with applicable requirements and to support timely and appropriate response to facility conditions; and
- conducting routine, preventive and emergency facility maintenance as needed for ER facilities to control the degradation of facilities and mitigate of contaminants and limit future risk or harm to human health and the environment.

Surveillance and Maintenance activities were conducted throughout FY 1996 at the RA facilities. Overall, the RA S\&M Program consists of approximately 650 acres that include 14 waste area groupings with approximately 200 sites. These sites include 46 major facilities, several leak and contaminated soil sites, 38 inactive tanks, approximately 50 environmental study areas and approximately 2973 wells and boreholes. Site inspections were conducted at established frequencies on appropriate sites in the RA S\&M Program in accordance with the established S\&M FY 1996 Incentive Task Order (ITO).

Surveillance and Maintenance activities were conducted throughout FY 1996 at the D\&D S\&M Program sites in accordance with published S\&M ITO. The D\&D S\&M Program maintains 46 facilities (buildings). It provides overall facility management on over $165,000 \mathrm{ft}^{2}$ of floor space that includes 46 major facilities consisting of four surplus reactors, radiochemical processing facilities, and technology development facilities. 
Section 1: Introduction

\section{INTRODUCTION}

The Surplus Facilities Management Program was established at Oak Ridge National Laboratory (ORNL) in 1976 to provide collective management of the surplus sites under ORNL control on the Oak Ridge Reservation (ORR). The program originally contained both civilian- and defense-related facilities. For several years, the administration of the civilian and defense programs were independent of one another. In 1989, the two programs were merged into the current ORNL Decontamination and Decommissioning (D\&D) program.

The majority of the ORNL facilities managed by the D\&D program and awaiting the decommissioning phase have been inactive for 10 to 25 years. Because of this time lapse and the abandoned status of the sites, structural deterioration has occurred to varying degrees. This degradation has taken the form of metal corrosion, leaking roofs, accumulation of debris, etc., resulting in a general loss of facility operability. Conversion of these facilities to a safe-storage condition is currently underway. Safe storage includes the removal of hazardous and externally contaminated radioactive substances from the facilities. In addition, periodic surveillances are conducted so that corrective measures can be taken for health, safety, or environmental concerns.

The ORNL Environmental Restoration (ER) Remedial Action (RA) Surveillance and Maintenance (S\&M) Program was established to manage historically contaminated inactive sites from the time of their discovery until the initiation of remedial actions. These sites are typically contaminated with radioactive materials and/or hazardous chemicals. Several RA sites are in the $S \& M$ program as a result of postremedial agreements contained in site
Federal Facilities Agreement (FFA) and Resource Conservation and Recovery Act (RCRA) permits.

During fiscal year (FY) 1990, the ER Program was formed to conduct remedial investigations and feasibility studies and perform RAs at ORNL (see Fig. 1). In past years, there have been two distinct S\&M Programs, one for the RA Program sites and facilities and the other for

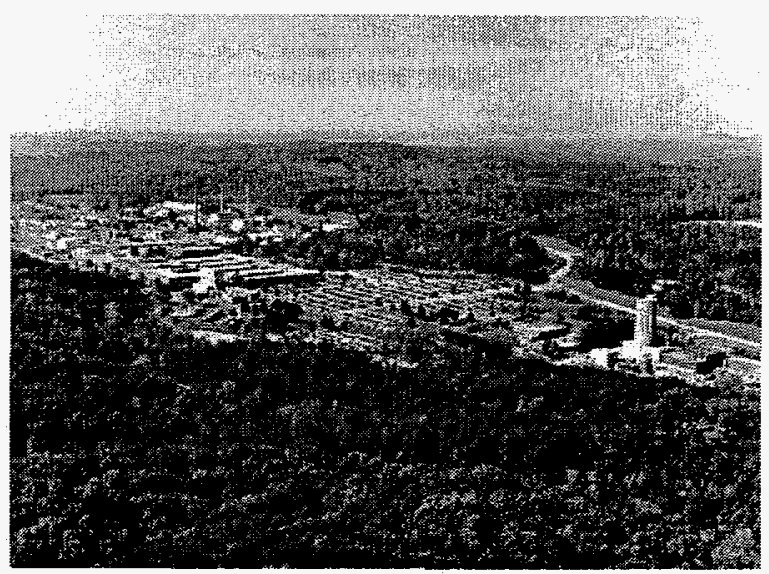

Fig. 1. Oak Ridge National Laboratory.

the D\&D Program sites and facilities. In FY 1995, the sites and facilities from both programs were combined to form the ORNL ER S\&M Program, which includes all ER-owned facilities [e.g., inactive liquid low-level waste (LLLW) storage tanks, impoundments, burial grounds, test sites, leak sites, contaminated soil, inactive reactor buildings, cooling towers, pump houses, evaporators, hot cells, wells and boreholes, and various research and development facilities]. In FY 1996, a new program management process, which used the Incentive Task Order (ITO) approach, was introduced. This ITO process was established to more efficiently manage the S\&M Program activities and their associated costs. The accomplishments of the RA S\&M Program will 
be discussed in Section 2 and the accomplishments of the D\&D S\&M Program will be discussed in Section 3.

The S\&M Program continues to manage and control areas contaminated with radioactive materials and/or hazardous chemicals. Management of the applicable areas or facilities follows their operating life and continues until final disposition or site stabilization (whichever is deemed most appropriate based on environmental regulations and/or best management practices).

\subsection{THE S\&M PROGRAM}

The ORNL ER S\&M Program provides the essential S\&M functions at applicable sites and facilities in an attempt to ensure that they remain in acceptable condition without undue risks to human health or the environment. (A list of these facilities is contained in Appendix A.) A map of the facilities located in Bethel Valley is shown in Fig. 2, and the facilities located in Melton Valley are shown in Fig. 3. The inventory of sites and facilities managed by the S\&M Program includes a variety of former reactors, hot cells, pilot plants, waste management areas, environmental research sites, and areas of contamination from past Research and Development operations. These facilities are all inactive.

\subsection{S\&M PROGRAM OBJECTIVES}

The principal objectives of the ORNL ER S\&M Program are as follows:

- conducting facility assessments as necessary to define and maintain baseline facility conditions;

- implementing a graded and cost-effective surveillance and inspection process for RA and D\&D facilities to ensure compliance with applicable requirements and to support timely and appropriate response to facility conditions; and

- conducting routine, preventive, and emergency facility maintenance as needed at ER facilities to control the degradation of facilities and migration of contaminants and to limit future risk or harm to human health and the environment.

These objectives are met through a structured program of routine $S \& M$ actions and through the implementation of special maintenance activities when site-surveillance activities indicate such are needed. The scope of activities performed within the ORNL ER S\&M Program provides assurance that adequate site control is achieved and maintained until final site decommissioning or closure is accomplished.

The ORNL ER S\&M Program is also responsible for all S\&M of a facility following final remediation. The ORNL ER S\&M Program activities are organized and conducted in the principal areas as described below:

1. S\&M Program Integration. S\&M program integration includes strategic programmatic planning, documentation, and reporting. It ensures that regulatory compliance- and milestone-related issues are incorporated into the development of technical, schedule, and cost baselines. All S\&M programmatic documents are written, edited, revised, published, and distributed through this element. This element is designed to ensure that applicable FFA and S\&M milestones are met. It includes preliminary radiological assessments of potentially contaminated sites and data management activities to provide access to historical solid and liquid waste disposal data for the inactive sites. This element also supports project management. Project management includes directing, staffing, coordinating, 
Section 1: Introduction

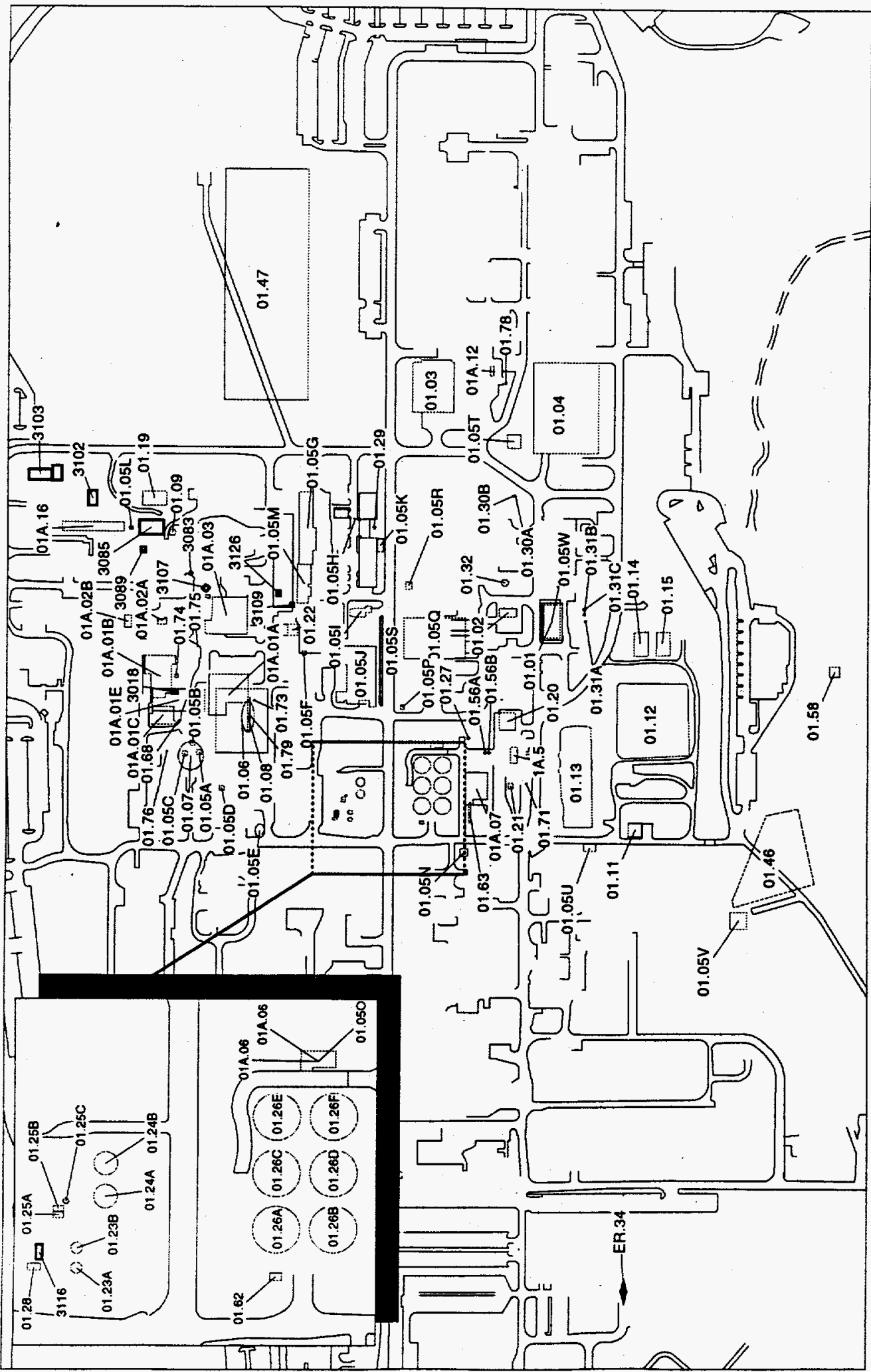

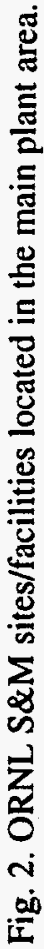




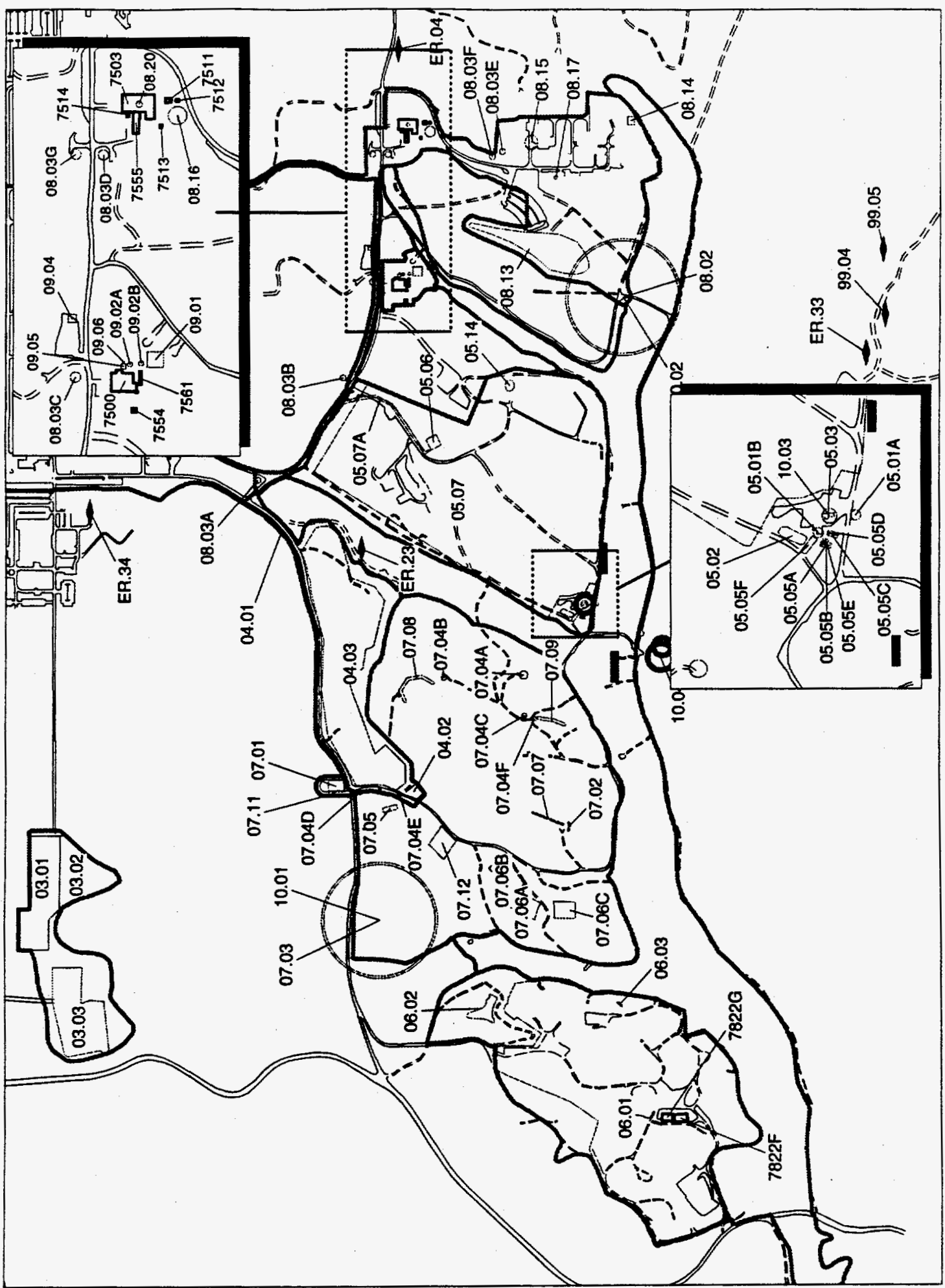

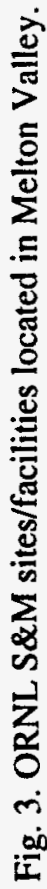


developing, and planning for each of the ORNL ER S\&M Program's S\&M activities. It coordinates, integrates, and furnishes the roles and responsibilities of Lockheed Martin Energy Systems, Inc., and other subcontractors. Also, it provides for the assignment of administrative duties that are required for the ORNL ER S\&M Program's financial management.

2. Routine S\&M. Routine S\&M supports all field work and related activities necessary to perform routine S\&M of ORNL ER S\&M Program sites until final remediation. Routine S\&M actions are necessary to ensure that ORNL ER S\&M Program sites are routinely maintained in a manner that protects human health, safety, and the environment. For such protective purposes, this element provides five distinct tasks as follows:

- routine site inspections, consisting of facility check sheets and logbooks;

- radiological and industrial hygiene surveillance, and inactive LLLW tank level monitoring;
- S\&M of ORNL groundwater monitoring and investigation wells that have been identified as unusable or nonessential;

- nonroutine activities that are required as a result of a finding during routine site inspections; and

- routine maintenance of containment systems and equipment, general facility upkeep, grounds maintenance, and oversight of all field maintenance activities.

3. Post Remediation Monitoring and Maintenance. Post remediation monitoring and maintenance activities are determined by the requirements of the perspective RCRA post-closure permit or Comprehensive Environmental Response, Compensation, and Liability Act Record of Decision. 


\section{FY 1996 RA S\&M PROGRAM ACCOMPLISHMENTS}

\subsection{PROGRAM INTEGRATION}

\subsubsection{Audits, Reviews, and Assessments}

The facility manager completed a Nuclear Criticality Safety Assessment for Solid Waste Storage Area (SWSA) 5 and SWSA 6. An audit of waste handling activities was performed by the ORNL Waste Certification Group against the Waste Management/Waste Certification Plan (ORNL/ER-288) with no findings.

\subsubsection{Plans, Reports, and Coordinating Documents}

The following documents were completed during FY 1996:

- Draft Facility Management Plan for the ORNL ER Program (ORNL/ER-194);

- $\quad$ Submitted to the U.S. Department of Energy (DOE) the Basis for Interim Operation for the Pits, Trenches, and Auger Holes in Waste Area Groupings (WAGs) 4 and 6; and

- Annual Summary Report on the Surveillance and Maintenance Activities for the Oak Ridge National Laboratory Environmental Restoration Program for Fiscal Year 1995 (ORNL/ER-345).

\subsubsection{Safety Documentation}

During FY 1995, the ER Program identified those facilities that were believed to require additional Facility Authorization Basis (FAB) documentation. In FY 1996, the ER Program prepared draft or final FAB documentation on every facility for which it was required.
An initial list of 166 Preliminary Hazard Screenings (PHSs) included many facilities that were either part of a larger grouping or did not meet the definition of a "facility" for purposes of safety documentation. Analysis of the regulatory requirements and coordination with the Office of Operational Readiness and Facility Safety reduced this list to a more manageable list of 68 facilities. As the documentation progressed, it was determined that some of the sites had already been addressed in existing documents. Others were placed into groups of similar sites to increase the efficiency of administration. By the end of FY 1996, a total of nine PHSs had been performed on facilities or groups, and memos were written to file for the facilities that did not require further documentation. This action resulted in the elimination of an estimated $\$ 1.5 \mathrm{M}$ in projected unneeded safety documentation for 103 former sites and met an ITO fee milestone. Also, inactive LLLW tank T-30 was identified as requiring additional safety documentation.

\subsubsection{Columbus Initiatives}

Cost saving initiatives were processed through the Environmental Management and Enrichment Facilities organization as Columbus Initiatives. Before negotiation of the task order contract, numerous proposals for Columbus Initiatives were suggested by $S \& M$ program personnel and evaluated for submission to the internal review board. Approximately $\$ 2.9 \mathrm{M}$ of cost savings were documented and submitted. Of the proposals that were submitted, approximately $\$ 872 \mathrm{~K}$ in cost savings were approved by DOE. Columbus Initiatives approved in FY 1996 were

- Waste Area Grouping 4 seeps,

- Corehole 8 drain, 
- Inactive Facilities Grouping for Safety Documentation, and

- ORNL Inactive Facility S\&M Cost Reduction (non-fee bearing).

\subsubsection{No Further Investigation Sites}

An active program has been under way to achieve No Further Investigation status, under the FFA, for study area sites that are small in area and low in potential hazard. It is an integrated effort, involving personnel from ORNL ER, DOE, and the Tennessee Department of Environment and Conservation. The effort for this was funded in FY 1995, and the actual approval was received in FY 1996. Sites approved this year consist of the following:

- ER20 Tc-95 Uptake studies

- ER19 Tc-95M Contaminated Soil and Plants

- ER07 Cs-45 Tagged Forest

- ER05 Hg-197 Tagged Stream

- ER09 Hg-203 Tagged Stream

- ER13 Zn-65 Tagged Red Oak Saplings

- ER10 H-3 Contaminated Trees

- ER33 C-14 Efflux in Yellow Poplar Stand

- ER32 C-14 Allocation in White Pine Trees

- ER30 C-14 Sucrose Inoculation of Oak and Pine Trees

- ER29 C-14 Maintenance-Respiration Study

- ER28 Co-60 and Mn-54 Animal Study

- ER27 Cs-134 Contaminated Persimmon Tree

- ER31 C-14 Allocation in White Oak Trees

\subsection{ROUTINE SURVEILLANCE}

In accordance with Site Inspection Procedures, 212 facilities under the RA S\&M program were periodically inspected; in addition, all signs and radiation boundary markers were checked and repaired as needed. Monthly Tank Level Data Reports were compiled and published. Monitoring of the french drain levels at WAG 5 Seeps C and D were performed (see Figs. 4 and 5). Additionally, an annual inspection was performed on 268 monitoring wells. Coordination of S\&M inspection activities was improved by establishing a method of providing Field Change Orders to the subcontractor responsible for the routine inspections. This allows rapid response to changes and deletions in inspection requirements.

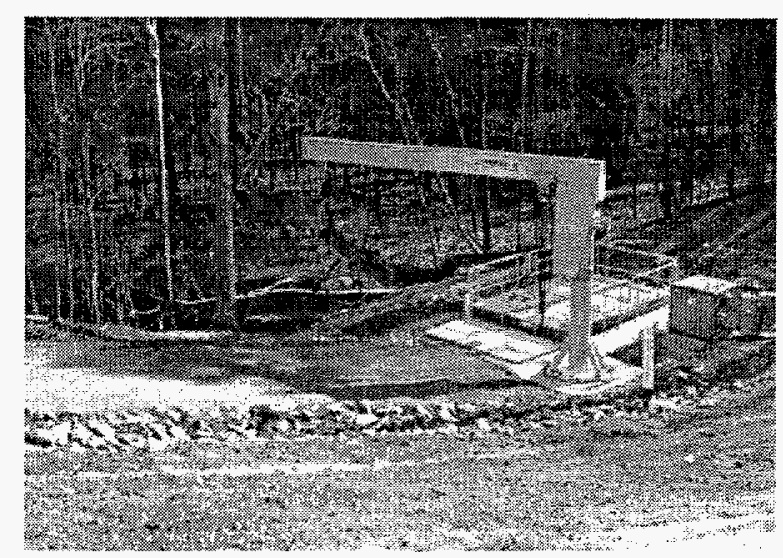

Fig. 4. WAG 5 Seep C.

\subsection{MAINTENANCE}

General maintenance activities include subsidence fills, signs, boundary fences, gates, road repairs, and vegetation control; other unscheduled maintenance activities were accomplished as needed.

\subsubsection{Surface Impoundment}

The south earthen bank of the impoundment had begun to deteriorate, requiring repair and reinforcement to mitigate or eliminated a leak from the impoundment to White Oak Creek (see Fig. 6). Engineering studies were completed, the area was reinforced with crushed rock, sprayed with bentonite, and markers emplaced to track embankment shifting. 
Section 2: FY 1996 RA S\&M Program Accomplishments

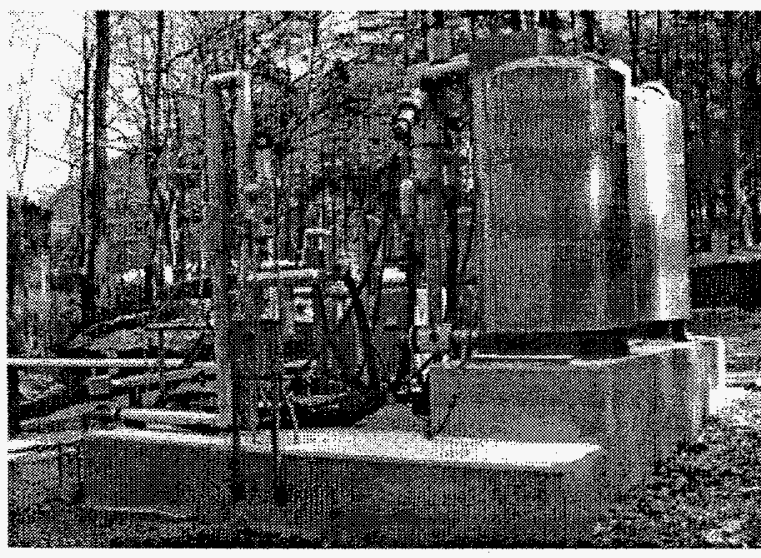

Fig. 5. WAG 5 Seep $D$.

\subsubsection{Ventilation Systems}

Changed high-efficiency particulate air filters and verified efficiency of the ventilation systems at the Old Hydrofracture Facility Tanks and Pumphouse and at the South Tank Farm.

\subsubsection{WAG 5 Seep C and D Treatment}

Routine maintenance was performed at Seep D. During the year, a problem was identified with the Zeolite ion exchange resin becoming plugged with iron oxide at Seep C. The resin was changed out, improving the flow. Plans have been formulated to treat the system with a reducing agent to prolong the life of the resin. A design change and relocation of the nitrogen bottle bank that is part of the Seep C treatment

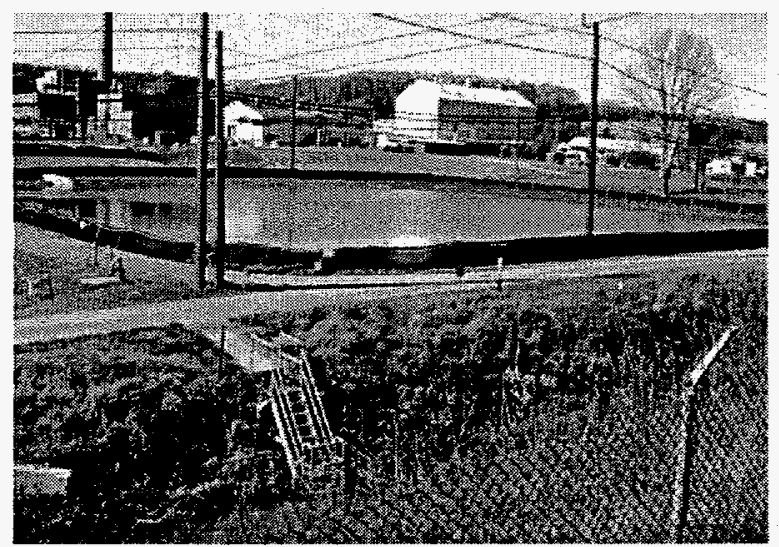

Fig. 6. 3513 Impoundment. system resulted in a larger number of bottles stored on-site and eliminated the need for wearing anticontamination clothing during bottle changing. This significantly improved efficiency and also permitted a larger number of bottles to be delivered at one time, reducing delivery frequency and overall cost.

\subsubsection{Vegetation Control}

Vegetation maintenance is continuously required for a variety of purposes, including mowing and trimming grass (see Fig.7), and removing downed trees and vegetation resulting from abnormal storm events. Other purposes might include upgrading the appearance of a site or

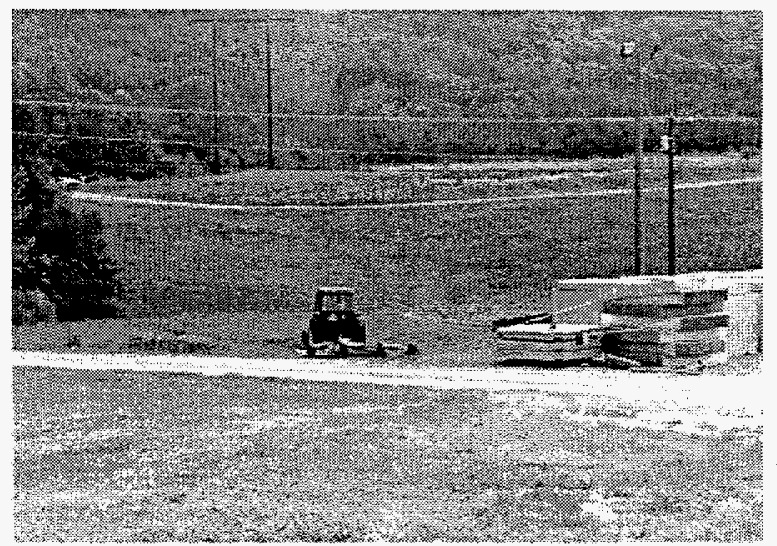

Fig. 7. Vegetation Control.

facility, permitting access for field activities, or enhancing the inspection processes. During FY 1996, vegetation maintenance was routinely performed at numerous areas (approximately 250 acres) that include the White Oak Creek Sediment Retention Embayment, the hydrofracture facilities, and various SWSAs, ponds, tank farms, fence lines, trenches, and pits. A policy of removal of dead and damaged trees from either side of the 229 boundary fences around the WAGs in compliance with 10 CFR-860 was initiated to minimize fence damage and emergency maintenance required from falling trees. The cutting will be completed in FY 1997. 


\subsubsection{Subsidence Fills}

Approximately 24 subsidences of varying sizes were backfilled in the SWSA 4 and SWSA 5 area (see Fig. 8).

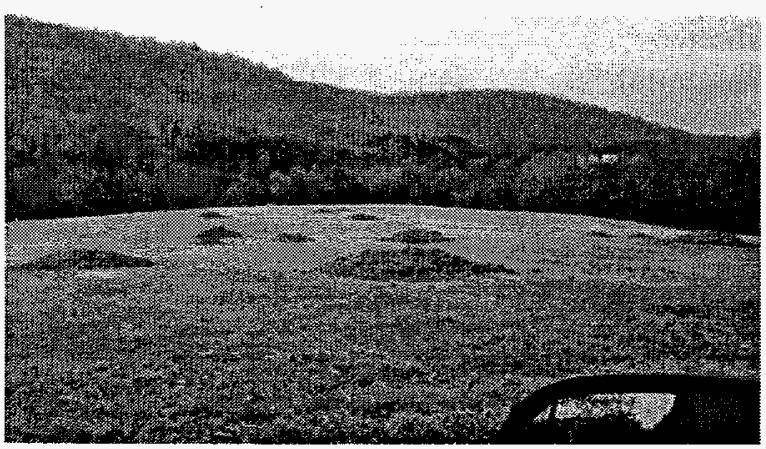

Fig. 8. Subsidence Repairs in SWSA 5.

\subsubsection{Fences and Roads}

Fence and road repairs were performed when necessary to ensure boundary integrity and enhance travel across the complex.

\subsubsection{Canal Clean-up}

In addition to the routine maintenance activities in FY 1996, the 3001 Canal Clean-up Task was conducted as an RA maintenance activity and is phase one of a two phase action to remediate the canal. A RCRA closure had been conducted in 1992 , when sludge contaminated with heavy metals was removed, leaving several containers of radioactive material in place. Activities leading up to the current action included preparation of the following documents:

- Site Safety and Health Plan

- ALARA Plan

- Comprehensive Work Plan

- NEPA evaluation

- Cost estimates

- Schedules
Work was accomplished under time constraints because of the need to limit personnel stress from heat while working in level $\mathrm{C}$ protective clothing. Individuals were allowed to work no more than 1.25 hours without relief. Existing cranes in the canal area were certified, under ORNL quality procedures, so that they could be used for lifting during the clean out. Chemical Technology Division personnel performed the work. Altogether, 2268 pounds of solid waste was removed, containing approximately $96 \mathrm{Ci}$ of mixed radioisotopes. This action was completed in August 1996 and is a major milestone toward final stabilization of the canal.

\subsubsection{Melton Valley}

The following actions were accomplished in FY 1996:

- $\quad$ pumped nearly 4 million gallons of uncontaminated water from the 7821 Emergency Waste Basin (see Fig. 9);

- permanently closed a gap in the three-strand wire fence west of WAG 2 and WAG 8 to prevent uncontrolled access to WAGs $2,4,5$, and 7 ;

- $\quad$ repaired four monitoring wells in WAG 8 that were damaged in 1994 during the power line right-of-way clearing. Erected three "Jersey Bouncers" and a chain and lock at the eastern end of Melton Branch Road to close a gap created by power line clearing;

- installed signs around the perimeter of all WAGs in compliance with 10CFR-860; and

- relocated PCM1B monitor and trailer from WAG 5 to the north tank farm to support the Gunite and associated tanks sludge mobilization project and other field work in WAG 1. 
Section 3: FY 1996 D\&D S\&M Program Accomplishments

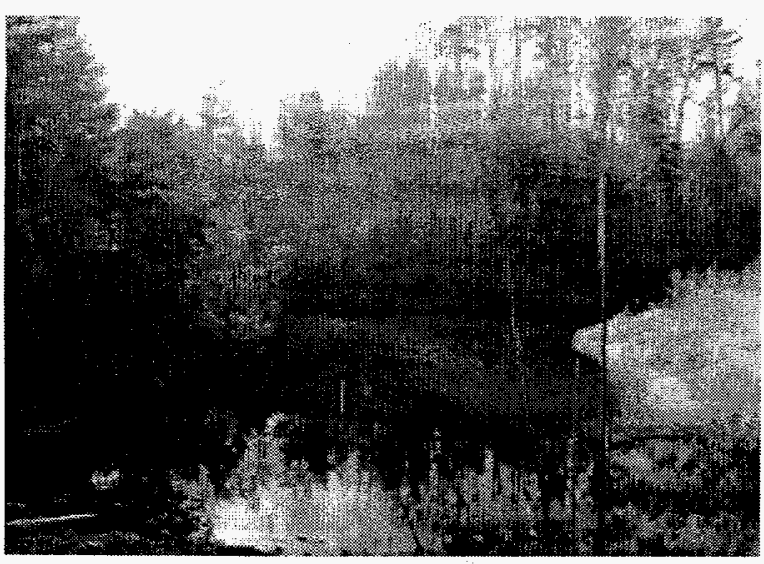

Fig. 9. Emergency Waste Basin.

\subsubsection{Bethel Valley}

Installed contamination barrier for soil contamination area at Building 3042.

Provided Facility Management support to the 3513/3524 Surface Impoundment Engineering Support Studies for installing the laboratory trailer, hooking up the utilities, and obtaining the permit for the trailer fume hood.

\subsection{POST REMEDIATION MONITORING}

- WAG 5 Seeps C and D-Water samples are taken routinely to verify that efficiency of Sr-90 removal is within limits.

- SWSA 6 RCRA Caps-Under the closure plan, the caps were inspected monthly by S\&M program personnel (see Fig. 10).

- 3001 Canal-Water samples are taken to determine levels of Cs-137, Co-60, and Sr-90. This data is used to determine frequency of water demineralizer resin regeneration.
- Corehole 8-The Corehole 8 outfall was a significant contributor of Sr-90 to White Oak Creek. The water is now collected and pumped to the Process Waste Treatment Plant. Monitoring of the collection system includes responding to high water level alarms, sampling the water annually, and performing other associated surveillance and maintenance activities to ensure the reliable functioning of the system.

- Inactive Tank Closures-Four FFA Category D LLLW tanks were remediated by the ER Program and transitioned into the S\&M Program. Monitoring includes inspection for subsidence, and surface anomalies, drain closure integrity, and changes in nearby groundwater contaminants.

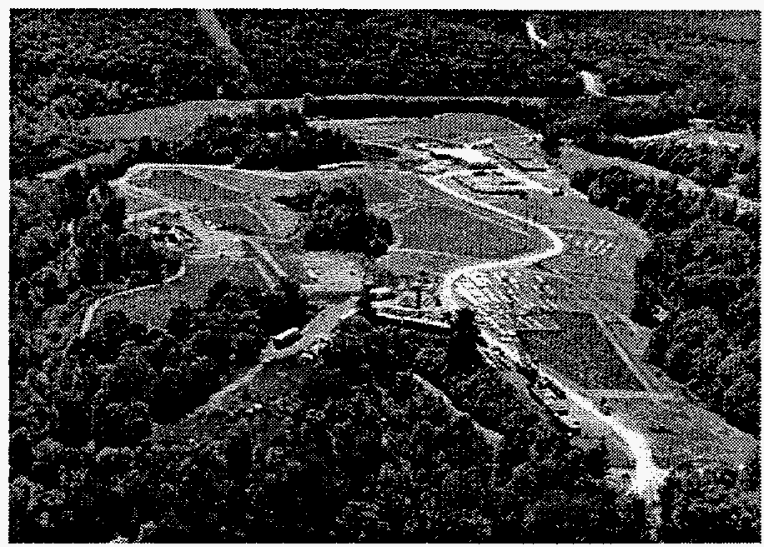

Fig. 10. SWSA 6 RCRA Caps. 
Section 3: FY 1996 D\&D S\&M Program Accomplishments

\section{FY 1996 D\&D S\&M PROGRAM ACCOMPLISHMENTS}

\subsection{PROGRAM INTEGRATION}

\subsubsection{Audits, Reviews, and Assessments}

Supported the 1996 LLLW survey conducted by Waste Management Operations.

\subsubsection{Plans, Reports, and Coordinating Documents}

Key D\&D documents completed for the ORNL S\&M Program included the following:

- Developed a Memorandum of Aggrement (MOA) for Buildings 7500, 3001, and 3005 (see Fig. 11) between divisions that had people using these facilities for offices and change areas and the ER Program. The purpose of this agreement was to share the cost of utilities with the ER Program and obtain agreement to a date when these facilities would be vacated to even further reduce the coordination complexity and S\&M cost of these facilities. By the end of FY 1996, many of the people had moved out of Building 3001, and Building 3042 offices had been vacated. Building 3005 is currently used by Instrumentation and Controls and Plant and Equipment divisions for offices and maintenance shops.

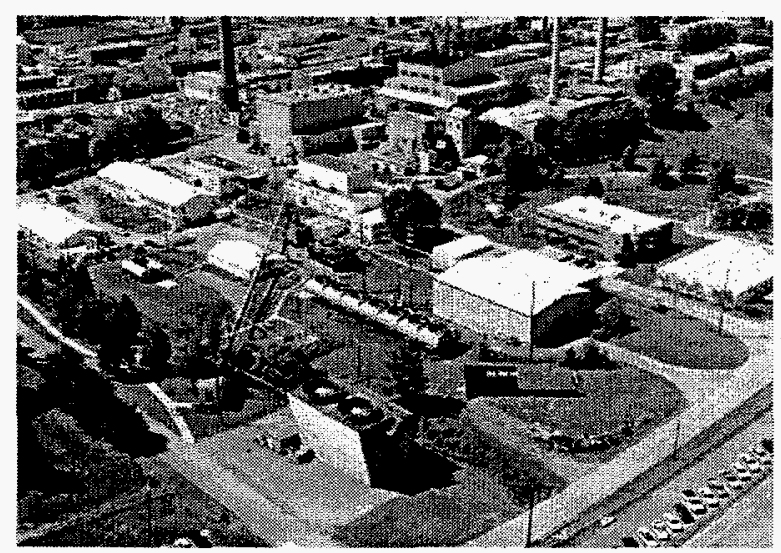

Fig. 11. Buildings 3001, 3005, and 3042.
- Completed the Local Emergency Manual for Buildings 3042, 3005, and 3001.

- $\quad$ Replaced the Waste Management Remedial Action Division surveillance procedures with ERPS 403, "Routine Surveillance Activities at the D\&D Program Facilities at ORNL."

- undertook privatization of Building 7500 , the Homogeneous Reactor Experiment (HRE) (see Fig. 12). To do this a request for expressions of interest in privatization of this facility was published. This was accomplished by producing handouts for "industrial day" and the creation of a World Wide Web page about HRE with links to related site information pages.

- A proposal was prepared and presented to the Plant Safety Evaluation Team (PSET) committee on the revision of the Limited Conditions Document (LCD) for the Oak Ridge Research Reactor.

\subsubsection{Safety Documentation}

The D\&D S\&M program completed an aggressive initiative to upgrade the status of safety documentation for its facilities this year. The regulatory environment has been somewhat turbulent recently, with changes and cancellation of several DOE orders that drive safety management. One result of these regulatory changes has been that the Office of Operational Readiness and Facility Safety adopted a policy that all radiological facilities would have an Auditable Safety Analysis (ASA). For efficiency, the lower-tier safety documents that had been prepared for small facilities were eliminated by combining, to the maximum extent feasible, all the ancillary facilities associated with a larger activity. For the 
Section 3: FY 1996 D\&D S\&M Program Accomplishments

surplus reactors and radiochemical processing facilities, this would include such items as cooling towers, valve pits, heat exchangers, and similar structures. Inactive tanks remained the responsibility of the Inactive Tank program. By the end of FY 1996, draft ASAs had been prepared for the Oak Ridge Research Reactor, the Oak Ridge Graphite Reactor (OGR), the Low-intensity Test Reactor, HRE, and the Metal Recovery Facility. It is anticipated that they will be finalized and approved early in FY 1997.

Aside from the $\mathrm{FAB}$ requirements, a question surfaced through the PSET committee related to the start-up of processing activities at Building 3019. The concern was that if an accident were to occur, visitors to the OGR, immediately next door, could be exposed to radioisotopes. After meeting with the PSET Committee, it was decided that the OGR Local Emergency Manual would address the problem adequately, with appropriate revisions and training for the Local Emergency Squad personnel. The manual was revised, with particular attention to actions necessary to protect visitors. The document was coordinated with the PSET Committee and the Laboratory Emergency Preparedness Department, and the final draft was approved. Training was prepared and conducted for the Local Emergency Squad members, emphasizing their role in controlling and protecting visitors who may be present during a drill or emergency.

\subsection{FACILITY SURVEILLANCE}

Facility surveillance was conducted on a daily basis in accordance with Procedure ERPS-403. Any findings from these surveillances were processed on a priority basis as resources permitted.

\subsection{ROUTINE MAINTENANCE}

Facility Maintenance activities performed throughout FY 1996 included the following activities:

- $\quad$ submitted required Waste Pick-up Request for all waste generated during normal facility operations;

- investigated the feasibility of metering the utilities to Building 7500 in support of the privatization of that building;

- updated and issued the Limiting Conditions Document for Building 3042;

- $\quad$ sealed cracks in the 3002 canal;

- reviewed the in-leakage of water into the north sump pit at HRE;

- inspected ladders at Building 7500 and 3001 for safety concerns;

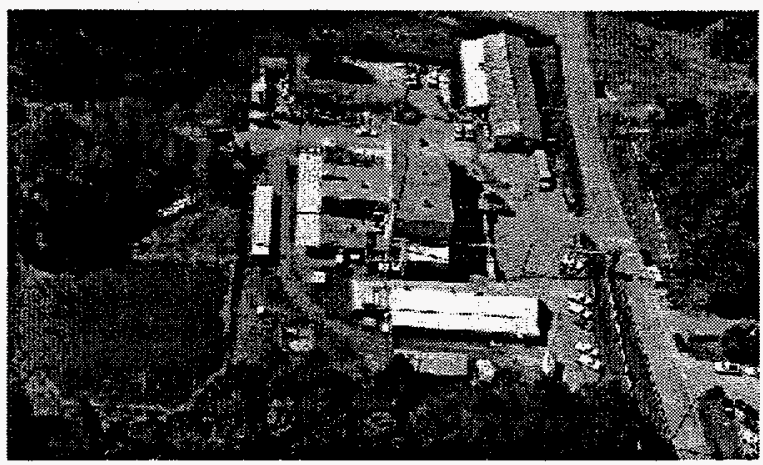

Fig. 12. Building 7500 the HRE Complex.

- initiated the removal of two Constant Air Monitors and one monitron, which are no longer required as a result of the Building 3042 LCD revision; 
- $\quad$ pumped the HRE hot storage pool (see Fig. 13);

- relamped the 3018 stack using the Plant and Equipment Division, instead of a subcontractor, and achieved cost savings of $\$ 100,000$;

- installed a ventilation flow meter in the OGR, which eliminted the need for a fan upgrade (this action resulted in a cost avoidance of $\$ 65,000$ );

- deactivated cooling towers for Building 3042 to reduce cost;

- $\quad$ fixed contamination areas by painting magenta and gray in buildings 3001 and 3002 ;

- $\quad$ relamped D\&D buildings as needed;

- installed access control gates in 3042 to control access to authorized personnel only;

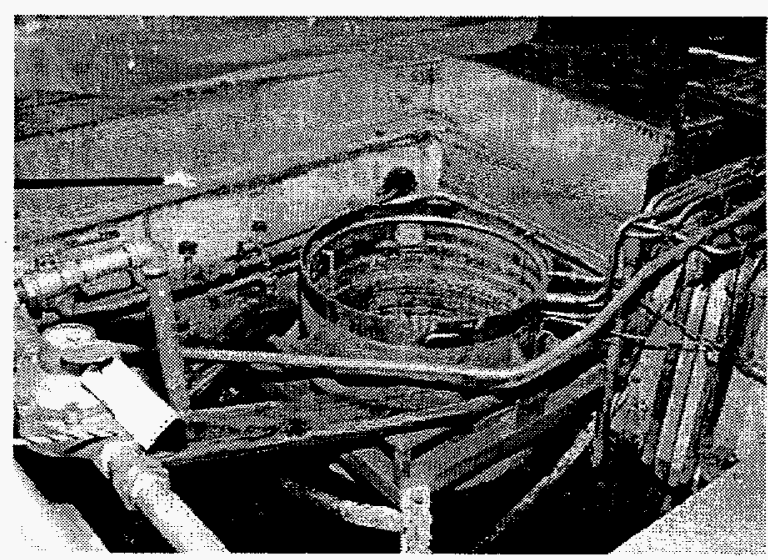

Fig. 13. HRE Storage pool.

- $\quad$ performed a filter efficiency test on exit ducts at buildings 3002,3005 , and 3042;

- labelled drains; and

- deactivated utilities as they became unnecessary. 
Appendix A

ORNL Surveillance and Maintenance Program Facility Management List 
Appendix A

ORNL ER Surveillance and Maintenance Program Facility Management List

\begin{tabular}{|c|c|c|c|c|}
\hline $\begin{array}{l}\text { Facility } \\
\text { Number }\end{array}$ & FFA & $\begin{array}{l}\text { Facility } \\
\text { Name }\end{array}$ & $\begin{array}{l}\text { Fac. } \\
\text { Type }\end{array}$ & Program \\
\hline 0800 & & Cs-137 Contaminated Field & Area & RA \\
\hline 0807 & 13.02 & Cs-137 Erosion/Runoff Study Area & Area & $\overline{\mathbf{R A}}$ \\
\hline 0814 & & Trailer & Bldg. & $\mathbf{R A}$ \\
\hline 0816 & 13.01 & Experimental Study Area (Cs-137 Plots) & Area & $\mathbf{R A}$ \\
\hline 0830 & & White Oak Creek Embayment Sediment Control Facility & Area & $\mathbf{R A}$ \\
\hline 0853 & & White Oak Creek and Tributaries & Area & \\
\hline 0857 & & Goat Building & Bldg. & RA \\
\hline 1001 & 03.01 & SWSA 3 Burial Grounds & Area & RA \\
\hline 1554 & 03.03 & Contractors' Landfill (West of SWSA 3) & Area & $\mathbf{R A}$ \\
\hline 1562 & 03.02 & Scrap Metal Area & Area & RA \\
\hline 2624 & 01.46 & SWSA 1 Burial Grounds & Area & $\mathbf{R A}$ \\
\hline 3001 & $01 \mathrm{A.01A}$ & Oak Ridge Graphite Reactor & Bldg. & RA \\
\hline 3001 & 01.79 & Storage Canal & Area & $\mathbf{R A}$ \\
\hline $3001 / 3019$ & 01.08 & Graphite Reactor Storage Canal Contaminated Soil & Area & RA \\
\hline $3001-3003$ & 01A.01E & Underground Exhaust Ducts Soil Contamination & Area & RA \\
\hline $3001 B$ & 01.73 & Inactive LLLW Collection Tank 3001B & Tank & $\mathbf{R A}$ \\
\hline 3002 & $01 \mathrm{~A} .01 \mathrm{C}$ & OGR Filter House \& Canal & Bidg. & D/D \\
\hline 3003 & $01 \mathrm{A.01B}$ & OGR Fan House & Bldg. & $D / D$ \\
\hline $3003 A$ & 01.74 & Drain Tank South of 3003 & Tank & RA \\
\hline $3004 \mathrm{~B}$ & 01.75 & Inactive LLLW Collection Tank 3004B & Tank & RA \\
\hline 3005 & $01 \mathrm{A.02A}$ & Low-Intensity Test Reactor & Bldg. & $D / D$ \\
\hline 3013 & 01.76 & Inactive LLLW Collection Tank 3013 & Tank & RA \\
\hline 3018 & $01 \mathrm{A.010}$ & OGR Stack & Bidg. & $\overline{D / D}$ \\
\hline 3023 & $01.23 \mathrm{~A}$ & Inactive LLLW Collection/Storage Tank W-1 & Tank & RA \\
\hline 3023 & $01.25 \mathrm{~A}$ & Inactive LLLW Collection/Storage Tank W-13 & Tank & RA \\
\hline 3023 & $01.25 \mathrm{~B}$ & Inactive LLLW Collection/Storage Tank W-14 & Tank & RA \\
\hline 3023 & $01.25 \mathrm{C}$ & Inactive LLLW Collection/Storage Tank W-15 & Tank & $\mathbf{R A}$ \\
\hline 3023 & 01.28 & Inactive LLLW Collection/Storage Tank W-1A & Tank & RA \\
\hline
\end{tabular}


Appendix A

ORNL ER Surveillance and Maintenance Program Facility Management List

\begin{tabular}{|c|c|c|c|c|}
\hline $\begin{array}{l}\text { Facillty } \\
\text { Number }\end{array}$ & FFA & $\begin{array}{c}\text { Facility } \\
\text { Name }\end{array}$ & $\begin{array}{l}\text { Fac. } \\
\text { Type }\end{array}$ & Program \\
\hline 3023 & $01.23 \mathrm{~B}$ & Inactive LLLW Collection/Storage Tank W-2 & Tank & RA \\
\hline 3023 & $01.24 \mathrm{~A}$ & Inactive LLLW Collection/Storage Tank W-3 & Tank & $\overline{R A}$ \\
\hline 3023 & $01.24 \mathrm{~B}$ & Inactive LLLW Collection/Storage Tank W-4 & Tank & RA \\
\hline 3028 & $01 \mathrm{A.09}$ & Strontium-90 Power Generators & Area & IDF \\
\hline 3037 & 01.29 & Inactive LLLW Collection/Storage Tank WC-1 & Tank & RA \\
\hline 3042 & $01 \mathrm{A.03}$ & Oak Ridge Research Reactor & Bidg. & $\mathrm{D} / \mathrm{D}$ \\
\hline 3042 & 014.03 & ORR Experimental Facilities (Basement) & Bldg. & $\mathrm{D} / \mathrm{D}$ \\
\hline 3075 & 01.19 & Decommissioned LITR Ponds & Area & $\overline{R A}$ \\
\hline 3077 & $01 \mathrm{A.02B}$ & Air Cooler - Low Intensity Test Reactor & Bldg. & $\mathrm{D} / \mathrm{D}$ \\
\hline 3083 & $01 \mathrm{~A} .03$ & Neutron Flight Tube Building & Bidg. & $D / D$ \\
\hline 3085 & $01 \mathrm{A.03}$ & Pumphouse for ORR & Bldg. & $\mathrm{D} / \mathrm{D}$ \\
\hline $3085 A$ & $01 A .03$ & 20,000 Gallon Water Tank & Tank & D/D \\
\hline $3085 B$ & $01 A .03$ & 20,000 Gallon Water Tank & Tank & $\mathrm{D} / \mathrm{D}$ \\
\hline 3086 & $01 \mathrm{A.03}$ & Cooling Tower for ORR (\#1) & Bldg. & $\mathrm{D} / \mathrm{D}$ \\
\hline 3087 & $01 A .16$ & ORR Trane Water-to-Air Heat Exchangers & Bldg. & $\mathrm{D} / \mathrm{D}$ \\
\hline 3089 & $01 \mathrm{A.03}$ & Cooling Tower for ORR (\#2) & Bldg. & $\mathrm{D} / \mathrm{D}$ \\
\hline 3102 & $01 A .03$ & Heat Exchanger for ORR ( $\# 2)$ & Bldg. & D/D \\
\hline 3103 & $01 \mathrm{~A} .03$ & Cooling Tower for ORR (\#3) & Bldg. & $\mathrm{D} / \mathrm{D}$ \\
\hline 3107 & $01 A .03$ & Neutron Flight Tube Building & Bldg. & $\mathrm{D} / \mathrm{D}$ \\
\hline 3109 & $01 A .03$ & Off-Gas Filters for ORR & Bldg. & $\mathrm{D} / \mathrm{D}$ \\
\hline 3110 & 01.22 & Filter House/lsotope Area Ductwork & Bldg. & RA \\
\hline 3116 & & Nitrogen Cylinder Storage Bldg. & Bldg. & RA \\
\hline 3126 & $01 A .03$ & Charcoal Filter (NOG) for ORR & Bldg. & $D / D$ \\
\hline 3139 & $01 \mathrm{~A} .03$ & Cell Ventilation Filter for ORR & Bidg. & D/D \\
\hline 3503 & 01.01 & Mercury Contaminated Soil & Area & $\overline{R A}$ \\
\hline 3505 & $01 A .07$ & Metal Recovery Facility & Bldg. & $\mathrm{D} / \mathrm{D}$ \\
\hline 3505 & 01.63 & Transfer Canal and Dissolver Pit & Bldg. & RA \\
\hline 3507 & $01.26 \mathrm{~F}$ & Inactive LLLW Collection/Storage Tank W-10 & Tank & $\mathbf{R A}$ \\
\hline 3507 & 01.27 & Inactive LLLW Collection/Storage Tank W-11 & Tank & RA \\
\hline
\end{tabular}




\section{Appendix A}

ORNL ER Surveillance and Maintenance Program Facility Management List

\begin{tabular}{|c|c|c|c|c|}
\hline $\begin{array}{l}\text { Facillity } \\
\text { Number }\end{array}$ & FFA & $\begin{array}{c}\text { Facillity } \\
\text { Name }\end{array}$ & $\begin{array}{l}\text { Fac. } \\
\text { Type }\end{array}$ & Prograin \\
\hline 3507 & $01.26 \mathrm{~A}$ & |Inactive LLLW Collection/Storage Tank W-5 & Tank & RA \\
\hline 3507 & $01.26 \mathrm{~B}$ & Inactive LLLW Collection/Storage Tank W-6 & Tank & $\mathbf{R A}$ \\
\hline 3507 & $01.26 \mathrm{C}$ & Inactive LLLW Collection/Storage Tank W-7 & Tank & $\mathbf{R A}$ \\
\hline 3507 & $01.26 \mathrm{D}$ & Inactive LLLW Collection/Storage Tank W-8 & Tank & RA \\
\hline 3507 & $01.26 \mathrm{E}$ & Inactive LLLW Collection/Storage Tank W-9 & Tank & $\mathbf{R A}$ \\
\hline 3507 Area & 01.21 & FPDL LLLW Transfer Line to STF & Area & $\mathbf{R A}$ \\
\hline 3512 & 01.11 & Decommissioned Waste Holding Basin & Area & $\mathbf{R A}$ \\
\hline 3513 & 01.12 & Waste Holding Basin & Pond & RA \\
\hline 3515 & $01 \mathrm{A.06}$ & Fission Product Pilot Plant & Bldg. & $\mathrm{D} / \mathrm{D}$ \\
\hline 3517 & 01.20 & Fission Product Development Laboratory & Bldg. & IDF \\
\hline 3517 & $01 A .05$ & FPDL Inactive Cells \& Service Tunnel & Bldg. & $\mathrm{D} / \mathrm{D}$ \\
\hline 3535 & & Filter Enclosure in South Tank Farm & Bldg. & $\mathbf{R A}$ \\
\hline 3592 & 01.02 & Mercury Contaminated Soil & Area & $\mathbf{R A}$ \\
\hline 4003 & 01.47 & SWSA 2 Burial Grounds & Area & $\mathbf{R A}$ \\
\hline 4501 & 01.03 & Mercury Contaminated Soil & Area & $\mathbf{R A}$ \\
\hline 4507 & $01 \mathrm{A.12}$ & High Radiation Level Chemical Development Lab & Bldg. & $\mathrm{D} / \mathrm{D}$ \\
\hline 4507 South & 01.78 & Inactive LLLW Collection Tank T-30 & Tank & $\overline{R A}$ \\
\hline 4508 & 01.04 & Mercury Contaminated Soil & Area & $\overline{R A}$ \\
\hline 4556 & & High-Level Chemical Development Lab Filter Pit & Bldg. & \\
\hline $7002 \mathrm{~A}$ & & Abandoned Underground Waste Oil Storage Tank & Tank & \\
\hline $7002 W$ & $17.02 \mathrm{~A}$ & Waste Oil Storage Tank & Tank & \\
\hline 7500 & 09A.01B & Homogenous Reactor Experiment & Bldg. & $\mathrm{D} / \mathrm{D}$ \\
\hline 7502 & 09.05 & Radioactive Waste Evaporator (Bldg. 7500) & Bldg. & D/D \\
\hline 7554 & $09 A .01 A$ & Cooling Tower (for Building 7500) & Bldg. & D/D \\
\hline 7556 & 09.01 & Homogeneous Reactor Experiment (HRE) Pond & Area & RA \\
\hline 7557 & $09 A .01 C$ & Charcoal Absorber Pit (for Building 7500) & Bldg. & $\mathrm{D} / \mathrm{D}$ \\
\hline 7558 & 09.06 & Waste Evaporator Loading Pit (for Bldg. 7500) & Bldg. & D/D \\
\hline 7559 & 09A.01D & Charcoal Absorber Valve Pit (for Bldg. 7500) & Bldg. & D/D \\
\hline
\end{tabular}


Appendix A

ORNL ER Surveillance and Maintenance Program Facility Management List

\begin{tabular}{|c|c|c|c|c|}
\hline $\begin{array}{l}\text { Facillity } \\
\text { Number }\end{array}$ & FFA & $\begin{array}{c}\text { Facillty } \\
\text { Name }\end{array}$ & $\begin{array}{l}\text { Fac. } \\
\text { Type }\end{array}$ & Program \\
\hline 7560 & 09.02A & LLLW Collection and Storage Tank 7560 & Tank & RA \\
\hline 7561 & 09A.01F & Waste Valve Pit 7561 (Decon Pit) & Bldg. & RA \\
\hline 7562 & $09.02 B$ & LLLW Collection and Storage Tank 7562 & Tank & RA \\
\hline 7563 & & Circulator Pump Pit (for Bldg. 7500) & Bidg. & $\bar{D} / \mathrm{D}$ \\
\hline $7569 \mathrm{C}$ & 19.07 & Soil Injection of Radioactive Gas & Area & RA \\
\hline 7613 & 18.05 & Waste Retention Basin & Area & $\overline{R A}$ \\
\hline 7615 & 18.02 & Paint Solvents Storage Tank & Tank & \\
\hline 7658 & 12.01 & Closed Contractors' Landfill & Area & $\mathbf{R A}$ \\
\hline $7659 \mathrm{~B}$ & 19.06 & Reactive Chemicals Disposal Area & Area & RA \\
\hline 7711 & 16.02 & Process Waste Basin & Area & $R A$ \\
\hline 7759 & 16.01 & Cesium-137 "Forest" Research Area & Area & RA \\
\hline 7800 & 04.03 & SWSA 4 Burial Grounds & Area & RA \\
\hline 7802 & 05.07 & SWSA 5 South (Trenches, Undefined Area, Dump, Auger Holes) & Area & RA \\
\hline $7802 A$ & & Seep Area C Collection and Treatment Unit (WAG 5) & Area & RA \\
\hline $7802 B$ & & Seep Area D Collection and Treatment Unit (WAG 2) & Area & $\mathbf{R A}$ \\
\hline $7802 \mathrm{C}$ & & Deep Monitoring Well \#1 & Well & $\mathbf{R A}$ \\
\hline 7802D & & Deep Monitoring Well \#2 & Well & RA \\
\hline 7805 & 07.05 & Chemical Waste Pit \#1 & Area & RA \\
\hline 7806 & $07.06 \mathrm{~A}$ & Chemical Waste Pit \#2 & Area & RA \\
\hline 7807 & 07.06B & Chemical Waste Pit \#3 & Area & RA \\
\hline 7808 & $07.06 \mathrm{C}$ & Chemical Waste Pit \#4 & Area & RA \\
\hline 7809 & 07.07 & Chemical Waste Trench \#5 & Area & RA \\
\hline 7810 & 07.08 & Chemical Waste Trench \#6 & Area & $\mathbf{R A}$ \\
\hline 7811 & 04.02 & Pilot Pits 1, 2 (7811) & Area & RA \\
\hline 7818 & 07.09 & Chemical Waste Trench \#7 & Area & RA \\
\hline 7819 & $07.10 \mathrm{~A}$ & Shielded Transfer Tank (7819 Shed) (ST1) & Tank & $\mathrm{D} / \mathrm{D}$ \\
\hline 7819 & 07.108 & Shielded Transfer Tank (7819 Shed) (ST2) & Tank & D/D \\
\hline 7819 & $07.10 \mathrm{C}$ & Shielded Transfer Tank (7819 Shed) (ST3) & Tank & D/D \\
\hline
\end{tabular}




\section{Appendix A}

ORNL ER Surveillance and Maintenance Program Facility Management List

\begin{tabular}{|c|c|c|c|c|}
\hline $\begin{array}{l}\text { Facillity } \\
\text { Number }\end{array}$ & FFA & $\begin{array}{l}\text { Facillity } \\
\text { Name }\end{array}$ & $\begin{array}{l}\text { Fac. } \\
\text { Type }\end{array}$ & Program \\
\hline 7819 & 07.100 & Shielded Transfer Tank (7819 Shed) (ST4) & Tank & $D / D$ \\
\hline 7819 & $07.10 \mathrm{E}$ & Shielded Transfer Tank (7819 Shed) (ST5) & Tank & $\mathrm{D} / \mathrm{D}$ \\
\hline 7819 & 07.01 & Interim Decontamination Building & Bldg. & OR \\
\hline 7821 & 06.02 & Emergency Waste Basin & Pond & RA \\
\hline 7822 & 06.01 & SWSA \#6 RCRA Caps & Area & RA \\
\hline 7822 & 06.01 & SWSA 6 & Area & RA \\
\hline 7822-A & 06.03 & SWSA 6 - Explosive Detonation Trench & Area & RA \\
\hline $7822 \mathrm{~F}$ & & Tumulus I & Area & RA \\
\hline $7822 G$ & & Tumulus II & Area & RA \\
\hline 7835 & 05.06 & Process Waste Sludge Basin & Area & $R A$ \\
\hline 7841 & 07.12 & Equipment Storage Area & Area & RA \\
\hline 7846 & & White Oak Lake and Embayment & Area & \\
\hline 7852 & 05.03 & Old Hydrofracture Facility Site Surface Facilities & Bldg. & $\mathrm{D} / \mathrm{D}$ \\
\hline 7852A & 05.02 & OHF Pond/Pits & Pond & RA \\
\hline HF-S1 & 10.01 & Hydrofracture Experimental Site \#1 & Area & RA \\
\hline HF-S1A & 07.03 & Hydrofracture Experimental Site \#1 Soil Contamination & Area & RA \\
\hline HF-S2 & 10.02 & Hydrofracture Experimental Site \#2 & Area & RA \\
\hline HF-S2A & 08.02 & Hydrofracture Experimental Site \#2 Soil Contamination & Area & $\mathbf{R A}$ \\
\hline HF-S3 & & Hydrofracture Experimental Site \#3 & Area & RA \\
\hline HF-S4 & & Hydrofracture Experimental Site \#4 & Area & RA \\
\hline WAG 8 & & Waste Area Grouping 8 & Area & RA \\
\hline WAG 2 & & Waste Area Grouping 2 & Area & RA \\
\hline WAG 9 & & Waste Area Grouping 9 & Area & RA \\
\hline XD0751 & 11.01 & White Wing Scrap Yand & Area & $\mathbf{R A}$ \\
\hline XF1226 & 20.01 & Municipal Sewage Sludge Application Site & Area & RA \\
\hline
\end{tabular}


Appendix A

ORNL ER Surveillance and Maintenance Program Facility Management List

\begin{tabular}{|c|c|c|c|c|}
\hline $\begin{array}{l}\text { Facility } \\
\text { Number }\end{array}$ & FFA & $\begin{array}{l}\text { Facility } \\
\text { Name }\end{array}$ & $\begin{array}{l}\text { Fac. } \\
\text { Type }\end{array}$ & Program \\
\hline & 99.01 & Abandoned Burn Pit & Area & RA \\
\hline & 08.17 & Abandoned Sanitary Waste Pipeline \& Septic Tank N of 7917 & Area & $\mathbf{R A}$ \\
\hline & 08.15 & Aircraft Reactor Experiment Surface Impoundment & Area & RA \\
\hline & $08 \mathrm{A.01G}$ & ARE Contaminated Tool Storage & Area & RA \\
\hline & 07.11 & Building 7819 Septic Tank & Area & OR \\
\hline & 16.03 & Buried Scrap Metal Area & Area & $\mathbf{R A}$ \\
\hline & ER.31 & C-14 Allocation in White Oak Trees & Area & RA \\
\hline & ER.32 & C-14 Allocation in White Pine Trees & Area & $\overline{R A}$ \\
\hline & ER.34 & C-14 Allocation in Woody Biomass Plantation Species & Area & RA \\
\hline & ER.33 & C-14 Efflux in Yellow Poplar Stand & Area & RA \\
\hline & ER.29 & C-14 Maintenance-Respiration Study & Area & RA \\
\hline & ER.30 & C-14 Sucrose Inoculation of Oak and Pine Trees & Area & RA \\
\hline & ER.07 & Ca-45 Tagged Forest & Area & RA \\
\hline & ER.02 & Ca-45 Tagged Soil and Vegetation & Area & $\overline{R A}$ \\
\hline & ER.01 & Ca-45 Tagged Trees & Area & RA \\
\hline & ER.28 & Co-60 and Mn-54 Animal Study & Area & RA \\
\hline & & Cobalt 60 Storage Garden & Area & \\
\hline & 01.08 & $\begin{array}{l}\text { Contaminated Surfaces \& Soil from } 1959 \text { Explosion, Building } 3019 \\
\text { Cell }\end{array}$ & Area & $\mathbf{R A}$ \\
\hline & 01.07 & Contamination at Base of 3019 Stack & Area & $\mathbf{R A}$ \\
\hline & 08.13 & Contractor Spoils Area - Melton Valley, W-SW of 7900 & Area & $\mathbf{R A}$ \\
\hline & 01.81 & Corehole 8 & Area & $\mathbf{R A}$ \\
\hline & ER.22 & Cr-51 Contaminated Grass Plots & Area & $\overline{\mathbf{R A}}$ \\
\hline & ER.17 & Cs-134 Contaminated Grasses & Area & RA \\
\hline & ER.18 & Cs-134 Contaminated Lichens and Mosses & Area & $\mathbf{R A}$ \\
\hline & ER.12 & Cs-134 Contaminated Oak Trees & Area & $\overline{\mathbf{R A}}$ \\
\hline & ER.27 & Cs-134 Contaminated Persimmon Tree & Area & RA \\
\hline & ER.14 & Cs-134 Contaminated Pine and Oak Seedlings & Area & RA \\
\hline & ER.16 & Cs-134 Contaminated Soybean and Sorghum & Area & $\mathbf{R A}$ \\
\hline
\end{tabular}


Appendix A

ORNL ER Surveillance and Maintenance Program Facility Management List

\begin{tabular}{|c|c|c|c|c|}
\hline $\begin{array}{l}\text { Facility } \\
\text { Number }\end{array}$ & FFA & $\begin{array}{c}\text { Facility } \\
\text { Name }\end{array}$ & $\begin{array}{l}\text { Fac. } \\
\text { Type }\end{array}$ & Program \\
\hline & ER.06 & Cs-134 Tagged Tree & Area & RA \\
\hline & ER.04 & Cs-137 Bagged Leaves Study & Area & RA \\
\hline & 99.04 & Cs-137 Contaminated Forest Floor & Area & RA \\
\hline & 99.05 & Cs-137 Contaminated Forest Understory & Area & $\mathbf{R A}$ \\
\hline$\cdot$ & 99.06 & Cs-137 Contaminated Meadow & Area & RA \\
\hline & 99.03 & Cs-137, Co-60 Contaminated Forest Area (Chestnut Ridge) & Area & RA \\
\hline & ER.08 & Cs-137, Fe-59 Contaminated Animal Pens (NcNew Hollow) & Area & $\mathbf{R A}$ \\
\hline & & Decontamination Area & Area & RA \\
\hline & $05.07 \mathrm{~B}$ & Drainage 1, 2 in WAG 5 & Area & $\mathbf{R A}$ \\
\hline & $05.07 \mathrm{C}$ & Drainage 3 next to WAG 5 & Area & RA \\
\hline & 19.08 & Explosive and Shock-Sensitive Waste Detonation Area & Area & \\
\hline & 01.20 & Filter Pit (Fission Product Development Lab) & Bldg. & $\overline{R A}$ \\
\hline & 01.58 & Former Waste Pile Area (South of NRWTP) & Area & $\mathbf{R A}$ \\
\hline & 00.33 & FPPP Contaminated Soil & Area & $\mathbf{R A}$ \\
\hline & & Freels Bend & Area & \\
\hline & 00.53 & Groundwater & Area & $\overline{R A}$ \\
\hline & $10.04 A$ & Grout Sheets & Area & $\mathbf{R A}$ \\
\hline & ER.10 & H-3 Contaminated Trees & Area & $\mathbf{R A}$ \\
\hline & 08.14 & HFIR Cooling Tower Surface Impoundment & Area & \\
\hline & ER.05 & $\mathrm{Hg}-197$ Tagged Stream & Area & $\mathbf{R A}$ \\
\hline & ER.09 & $\mathrm{Hg}-203$ Tagged Stream & Area & $\overline{\mathbf{R A}}$ \\
\hline & 07.02 & Homogeneous Reactor Experiment (HRE) Fuel Wells & Area & $\mathbf{R A}$ \\
\hline & O9A.01E & HRE Decontamination Pad & Area & RA \\
\hline & 01.71 & Inactive LLLW Collection Tank H-209 & Tank & RA \\
\hline & $01.56 \mathrm{~A}$ & Inactive LLLW Collection Tank W-19 & Tank & RA \\
\hline & $01.56 \mathrm{~B}$ & Inactive LLLW Collection Tank W-20 & Tank & RA \\
\hline & $01.31 \mathrm{~A}$ & Inactive LLLW Collection/Storage Tank TH-1 & Tank & RA \\
\hline & $01.31 \mathrm{~B}$ & Inactive LLLW Collection/Storage Tank TH-2 & Tank & RA \\
\hline
\end{tabular}


Appendix A

ORNL ER Surveillance and Maintenance Program Facility Management List

\begin{tabular}{|c|c|c|c|c|}
\hline $\begin{array}{l}\text { Facillity } \\
\text { Number }\end{array}$ & FFA & $\begin{array}{c}\text { Faclllty } \\
\text { Name }\end{array}$ & $\begin{array}{l}\text { Fac. } \\
\text { Type }\end{array}$ & Program \\
\hline & $01.31 \mathrm{C}$ & Inactive LLLW Collection/Storage Tank TH-3 & Tank & RA \\
\hline & 01.32 & Inactive LLLW Collection/Storage Tank TH-4 & Tank & RA \\
\hline & $01.30 \mathrm{~A}$ & Inactive LLLW Collection/Storage Tank WC-15 & Tank & RA \\
\hline & $01.30 \mathrm{~B}$ & Inactive LLLW Collection/Storage Tank WC-17 & Tank & RA \\
\hline & $05.05 \mathrm{~A}$ & Inactive OHF Waste Storage Tank T1 & Tank & RA \\
\hline & 05.05B & Inactive OHF Waste Storage Tank T2 & Tank & $\overline{R A}$ \\
\hline & $05.05 \mathrm{C}$ & Inactive OHF Waste Storage Tank T3 & Tank & RA \\
\hline & 05.05D & Inactive OHF Waste Storage Tank T4 & Tank & RA \\
\hline & 05.05E & Inactive OHF Waste Storage Tank T9 & Tank & RA \\
\hline & & Inactive Wells (Bethel Valley) & Well & RA \\
\hline & & Inactive Wells (Melton Valley) & Well & RA \\
\hline & & Lamberts Quarry & Area & \\
\hline & $07.04 E$ & Leak in Line Between Pit 3 and Trench 6 & Area & RA \\
\hline & 07.04D & Leak in Transfer Line from Decon Facility and Pit 1 & Area & RA \\
\hline & 07.04F & Leak in Valve Pit North of Trench 7 & Area & RA \\
\hline & 07.04B & Leak Site 1 Pit 6 SE & Area & RA \\
\hline & $07.04 \mathrm{C}$ & Leak Site 2 End of Trench 7 Access Road & Area & $\mathbf{R A}$ \\
\hline & $07.04 A$ & LLLW Leak Site at Gauging Station NW of Bldg. 7852 & Area & $\mathbf{R A}$ \\
\hline & $05.05 \mathrm{~F}$ & LLLW Line from Valve Box to OHF & Area & RA \\
\hline & $01.05 \mathrm{~K}$ & LLLW Lines \& Leak Sites - Between WC-1 \& W-5 & Area & RA \\
\hline & $08.03 \mathrm{C}$ & LLLW Lines \& Leak Sites - 7500 Area & Area & RA \\
\hline & $08.03 F$ & LLLW Lines \& Leak Sites - 7920 Ditch Line & Area & RA \\
\hline & $01.05 S$ & LLLW Lines \& Leak Sites - Abandoned Line Central Ave Area & Area & RA \\
\hline & $01.05 \mathrm{~F}$ & LLLW Lines \& Leak Sites - Between W-5 \& WC-19 & Area & $\mathbf{R A}$ \\
\hline & 08.03E & LLLW Lines \& Leak Sites - Bldg. 7920 \& MV Pumping Station Area & Area & RA \\
\hline & $01.05 \mathrm{~W}$ & LLLW Lines \& Leak Sites - Building 3503, Ground Contamination & Area & RA \\
\hline & $01.05 \mathrm{M}$ & LLLW Lines \& Leak Sites - Building 3028 & Area & RA \\
\hline & 01.051 & LLLW Lines \& Leak Sites - Building 3092 Area & Area & RA \\
\hline & $01.05 \mathrm{U}$ & LLLW Lines \& Leak Sites - Building 3518, West & Area & RA \\
\hline
\end{tabular}




\section{Appendix A}

ORNL ER Surveillance and Maintenance Program Facility Management List

\begin{tabular}{|c|c|c|c|c|}
\hline $\begin{array}{l}\text { Facillty } \\
\text { Number }\end{array}$ & FFA & $\begin{array}{l}\text { Facility } \\
\text { Name }\end{array}$ & $\begin{array}{l}\text { Fac. } \\
\text { Type }\end{array}$ & Program \\
\hline & $10.03 \mathrm{~A}$ & OHF Grout Sheets & Area & \\
\hline & 10.03 & Old Hydrofracture Injection Well & Well & RA \\
\hline & 05.14 & Old Landfill (NE Edge of SWSA 5 South) & Area & RA \\
\hline & & ORNL Area-wide Groundwater Program (Active Wells) & Area & RA \\
\hline & & $\begin{array}{l}\text { ORNL WAG } 10 \text { - Remedial Investigation OU\#3 - Hydrofracture Wells } \\
\text { and Boreholes }\end{array}$ & Area & RA \\
\hline & & Post 24 & Bldg. & RA \\
\hline & $05.07 A$ & PWSB Pipeline from PWSB to Process Waste Treatment Plant & Area & $\overline{R A}$ \\
\hline & ER.15 & Rb-86 Contaminated Plants & Area & RA \\
\hline & 00.44 & Soil at HRE Decontamination Pad/Shed & Area & RA \\
\hline & & Steam Cleaning Area & Area & RA \\
\hline & 01.10 & Storage Pad Between Bldgs 3053 and 3504 & Area & \\
\hline & & SWSA 4 Deer Fences & Area & RA \\
\hline & & SWSA 5 Deer Fences & Area & $\mathbf{R A}$ \\
\hline & 00.54 & SWSA 6 TVA Easement & Area & RA \\
\hline & ER.20 & Tc-95 Uptake Studies & Area & RA \\
\hline & ER.21 & Tc-95m and I-131 Contaminated Pasture & Area & RA \\
\hline & ER.19 & Tc-95m Contaminated Soil and Plants & Area & RA \\
\hline & ER.23 & Tc-99 \& Np-237 Contaminated Soil Lysimeters-Plutonium Floodplain & Area & RA \\
\hline & 99.10 & Thorium Storage Silos & Area & RA \\
\hline & 09.04 & Trash Area East of HRE Parking Lot & Area & $\mathbf{R A}$ \\
\hline & 00.50 & WAG 1 Groundwater & Area & $\mathbf{R A}$ \\
\hline & 00.52 & WAG 10 Groundwater & Area & $\mathbf{R A}$ \\
\hline & & WAG 4 Sr-90 Seeps & Area & $\mathbf{R A}$ \\
\hline & 00.61 & West End Dump Site & Area & \\
\hline & 00.51 & WOC Floodplain Soils \& Sediments & Area & $\mathbf{R A}$ \\
\hline & ER.13 & Zn-65 Tagged Red Oak Seedlings & Area & RA \\
\hline
\end{tabular}




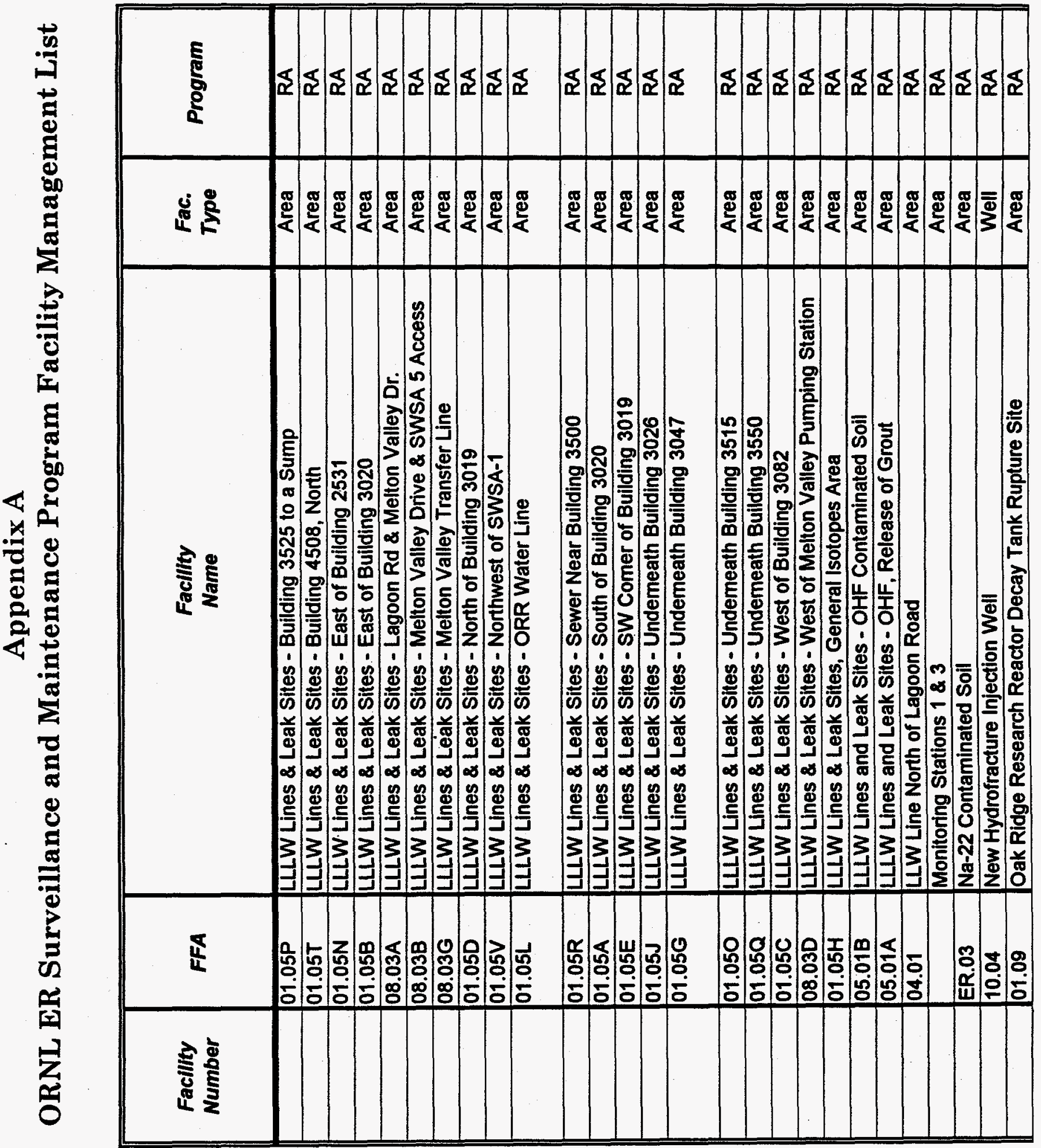


Appendix B

SUMMARY OF INACTIVE LLLW TANK LEVEL TRENDING ACTIVITIES 


\section{INTRODUCTION}

Oak Ridge National Laboratory (ORNL) currently has a total of 58 inactive liquid low-level waste (LLLW) storage tanks as defined in the Federal Facility Agreement (FFA) Appendix F list. These tanks are defined in Section IX (A)(d) of the FFA as Category D tanks because they are "existing tank systems that are removed from service." Twenty-one of the inactive tanks belong to and are managed by the Waste Management (WM) Program. The other thirty-seven tanks are owned and managed by the Environmental Restoration (ER) Program.

When the tanks were taken out of service, many tanks still had an inventory of liquids and/or sludges. ER established a surveillance and maintenance (S\&M) program to monitor the tank and its contents to protect human health and the environment.

\section{INACTIVE LLLW TANK LEVEL TREND ANALYSIS}

The following section contains tank level data for FY 1996. As required by the FFA, inactive LLLW tanks that are receiving non-programmatic inputs of liquid are monitored to maintain liquid level management. A monthly report is generated that tracks the liquid level trends of the tanks. The level trend analysis does not indicate that any of the $\mathbf{3 7}$ inactive LLLW tanks are outleaking.

\subsection{GUNITE STORAGE TANK W-5; SOUTH TANK FARM SITE, 3507, NORTH ROW}

Tank W-5 is a 170,000 gallon capacity tank constructed of gunite and reinforced steel. The liquid level has remained unchanged throughout FY 1995. The liquid level instrumentation is a Robertshaw Inven-Tel-185 conductivity probe which is connected to the Waste Operations Control Center (WOCC) which is manned 24 hours/day. This allows 24 -hour surveillance of the liquid level.

\subsection{GUNITE STORAGE TANK W-6; SOUTH TANK FARM SITE, 3507, SOUTH ROW}

Tank W-6 is a 170,000 gallon capacity tank constructed of gunite and reinforced steel. The tank liquid level has increased in FY 1996. This inleakage may be due to perched groundwater in the immediate vicinity of the tanks causing inleakage thru tank penetrations such as pipelines or tank access ports. The liquid level instrumentation is a Robertshaw Inven-Tel-185 conductivity probe which is connected to the WOCC which is manned 24 hours/day. This allows 24-hour surveillance of the liquid level.

\subsection{GUNITE STORAGE TANK W-7; SOUTH TANK FARM SITE, 3507, SOUTH ROW}

Tank W-7 is a 170,000 gallon capacity tank constructed of gunite and reinforced steel. The tank liquid level remained unchanged throughout FY 1995. The liquid level instrumentation is a Robertshaw Inven-Tel-185 conductivity probe which is connected to the WOCC which is manned 24 hours/day. This allows 24-hour surveillance of the liquid level.

\subsection{GUNITE STORAGE TANK W-8; SOUTH TANK FARM SITE, 3507, SOUTH ROW}

Tank W-8 is a 170,000 gallon capacity tank constructed of gunite and reinforced steel. The tank liquid level has increased in FY 1996. This inleakage may be due to perched groundwater in the immediate vicinity of the tanks

$$
\text { B - 3 }
$$


causing inleakage thru tank penetrations such as pipelines or tank access ports. The liquid level instrumentation is a Robertshaw Inven-Tel-185 conductivity probe which is connected to the WOCC which is manned 24 hours/day. This allows 24-hour surveillance of the liquid level.

\subsection{GUNTE STORAGE TANK W-9; SOUTH TANK FARM SITE, 3507, NORTH ROW}

Tank W-9 is a 170,000 gallon capacity tank constructed of gunite and reinforced steel. The tank liquid level has increased in FY 1996. This inleakage may be due to perched groundwater in the immediate vicinity of the tanks causing inleakage thru tank penetrations such as pipelines or tank access ports. The liquid level instrumentation is a Robertshaw Inven-Tel-185 conductivity probe which is connected to the WOCC which is manned 24 hours/day. This allows 24-hour surveillance of the liquid level.

\subsection{GUNITE STORAGE TANK W-10; SOUTH TANK FARM SITE, 3507, SOUTH ROW}

Tank W-10 is a 170,000 gallon capacity tank constructed of gunite and reinforced steel. The tank liquid level has increased in FY 1996. This inleakage may be due to perched groundwater in the immediate vicinity of the tanks causing inleakage thru tank penetrations such as pipelines or tank access ports. The liquid level instrumentation is a Robertshaw Inven-Tel-185 conductivity probe which is connected to the WOCC which is manned 24 hours/day. This allows 24-hour surveillance of the liquid level.

\subsection{TANK W-11; SOUTH EAST OF SOUTH TANK FARM}

Tank W-11 is a 15000 gallon capacity tank constructed of gunite and reinforced steel. The tank liquid level has increased in FY 1996. This inleakage may be due to perched groundwater in the immediate vicinity of the tanks causing inleakage thru tank penetrations such as pipelines or tank access ports. The liquid level is monitored daily with a staff gauge and this information is recorded on a database.

\subsection{OLD HYDROFRACTURE TANK}

Tank T-1 is a 15,000 gallon carbon steel tank. The liquid level is monitored daily with a Foxboro Model 13A DP transmitter. The liquid level has remained unchanged throughout FY 1996. The liquid level monitor was turned off January and February during sampling activities, and again from August through September during a campaign to install additional risers on the OHF tanks. These risers will be used to remove the contents in FY 1997 or 1998.

\subsection{OLD HYDROFRACTURE TANK}

Tank T-2 is a 15,000 gallon carbon steel tank. The liquid level is monitored daily with a Foxboro Model $13 \mathrm{~A}$ DP transmitter. The liquid level has remained unchanged throughout FY 1996. The liquid level monitor was turned off January and February during sampling activities, and again from August through September during a campaign to install additional risers on the OHF tanks. These risers will be used to remove the contents in FY 1997 or 1998. 
Tank T-3 is a 25,000 gallon carbon steel tank. The liquid level is monitored daily with a Foxboro Model 13A DP transmitter. The liquid level has remained unchanged throughout FY 1996. The liquid level monitor was turned off January and February during sampling activities, and again from August through September during a campaign to install additional risers on the OHF tanks. These risers will be used to remove the contents in FY 1997 or 1998.

\subsection{OLD HYDROFRACTURE TANK T-4}

Tank T-4 is a 25,000 gallon carbon steel tank. The liquid level is monitored daily with a Foxboro Model 13A DP transmitter. The liquid level has remained unchanged throughout FY 1996. The liquid level monitor was turned off January and February during sampling activities, and again from August through September during a campaign to install additional risers on the OHF tanks. These risers will be used to remove the contents in FY 1997 or 1998.

\subsection{OLD HYDROFRACTURE TANK T-9}

Tank T-9 is a 13,000 gallon carbon steel tank. The liquid level is monitored daily with a Foxboro Model 13A DP transmitter. The liquid level has remained unchanged throughout FY 1996. The liquid level monitor was turned off January and February during sampling activities, and again from August through September during a campaign to install additional risers on the OHF tanks. These risers will be used to remove the contents in FY 1997 or 1998.

\subsection{THORIUM TANK TH-1; SOUTH OF BUILDING 3503}

Tank TH-1 is empty. A conductivity probe is inserted through an access pipe to check for liquid level. No permanent level instrumentation is mounted to the tank.

\subsection{THORIUM TANK TH-2; SOUTH OF BUILDING 3503}

Tank TH-2 is empty. A conductivity probe is inserted through an access pipe to check for liquid level. No permanent level instrumentation is mounted to the tank.

\subsection{THORIUM TANK TH-3; SOUTH OF BUILDING 3503}

Tank TH-3 is empty. A conductivity probe is inserted through an access pipe to check for liquid level. No permanent level instrumentation is mounted to the tank. 


\subsection{THORIUM TANK TH-4; SOUTH OF BUILDING 3500}

Tank TH-4 is a 14,000 gallon capacity tank constructed of gunite and reinforced steel. The tank liquid level has increased in FY 1996. This inleakage may be due to perched groundwater in the immediate vicinity of the tanks causing inleakage thru tank penetrations such as pipelines or tank access ports. The liquid level instrumentation is a Robertshaw Inven-Tel-185 conductivity probe which is connected to the WOCC which is manned 24 hours/day. This allows 24-hour surveillance of the liquid level.

\subsection{TANK W-1; NORTH TANK FARM, NORTH OF CENTRAL AVENUE, SITE 3023}

Tank W-1 is a 4800 gallon capacity tank constructed of gunite and reinforced steel. The liquid level is slowly increasing. The tank liquid level has increased in FY 1996. This inleakage may be due to perched groundwater in the immediate vicinity of the tanks causing inleakage thru tank penetrations such as pipelines or tank access ports. The liquid level instrumentation is a Robertshaw Inven-Tel-185 conductivity probe which is connected to the WOCC which is manned 24 hours/day. This allows 24 -hour surveillance of the liquid level.

\subsection{TANK W-2; NORTH TANK FARM, NORTH OF CENTRAL AVENUE, SITE 3023}

Tank W-2 is a 4800 gallon capacity tank constructed of gunite and reinforced steel. The liquid level is slowly increasing. The tank liquid level has increased in FY 1996. This inleakage may be due to perched groundwater in the immediate vicinity of the tanks causing inleakage thru tank penetrations such as pipelines or tank access ports. The liquid level instrumentation is a Robertshaw Inven-Tel-185 conductivity probe which is connected to the WOCC which is manned 24 hours/day. This allows 24-hour surveillance of the liquid level.

\subsection{TANK W-3; NORTH TANK FARM, NORTH OF CENTRAL AVENUE, SITE 3023}

Tank W-3 is a 42,500 gallon capacity tank constructed of gunite and reinforced steel. The tank liquid level has increased in FY 1996. This inleakage may be due to perched groundwater in the immediate vicinity of the tanks causing inleakage thru tank penetrations such as pipelines or tank access ports. The liquid level instrumentation is a Robertshaw Inven-Tel-185 conductivity probe which is connected to the WOCC which is manned 24 hours/day. This allows 24-hour surveillance of the liquid level. Approximately 16,161 gallons of supernate was transferred to the active LLLW system in September, 1996, to maintain a safe liquid level.

\subsection{TANK W-4; NORTH TANK FARM, NORTH OF CENTRAL AVENUE, SITE 3023}

Tank W-4 is a 42,500 gallon capacity tank constructed of gunite and reinforced steel. The tank liquid level has increased in FY 1996. This inleakage may be due to perched groundwater in the immediate vicinity of the tanks causing inleakage thru tank penetrations such as pipelines or tank access ports. The liquid level instrumentation is a Robertshaw Inven-Tel-185 conductivity probe which is connected to the WOCC which is manned 24 hours/day. This allows 24-hour surveillance of the liquid level.. Approximately 23,839 gallons of supernate was transferred to the active LLLW system in September, 1996, to maintain a safe liquid level. 
Tank W-13 is a 2000 gallon capacity tank constructed of stainless steel. The tank remains empty. No permanent level instrumentation is mounted to the tank.

\subsection{TANK W-14; NORTH TANK FARM, NORTH OF CENTRAL AVENUE, SITE 3023}

Tank W-14 is a 2000 gallon capacity tank constructed of stainless steel. The tank remains empty. No permanent level instrumentation is mounted to the tank.

\subsection{TANK W-15; NORTH TANK FARM, NORTH OF CENTRAL AVENUE, SITE 3023}

Tank W-15 is a 2000 gallon capacity tank constructed of stainless steel. The tank remains empty. No permanent level instrumentation is mounted to the tank.

\subsection{TANK W-1A; NORTH TANK FARM, NORTH OF CENTRAL AVENUE, SITE 3023}

Tank W-1A is a 4000 gallon capacity tank constructed of stainless steel. The tank liquid level is monitored daily with a Foxboro 823 pneumatic gauge. This tank receives significant amounts of inleakage, with a total of 15 transfers made during FY 1996.

\subsection{TANK WC-1; BETWEEN BLDG. 3038 AND 3037, NORTH OF CENTRAL AVENUE}

Tank WC-1 is a 2150 gallon capacity tank constructed of stainless steel. The liquid level has remained unchanged throughout FY 1996. No permanent liquid level instrumentation is mounted to the tank.

\subsection{TANK WC-15; SOUTH OF BUILDING 3587, CORNER OF WHITE OAK AVE. AND FIFTH ST.}

Tank WC-15 is a 1000 gallon capacity tank constructed of stainless steel. The tank liquid level is monitored daily with a Robertshaw Inven-Tel 185 model conductivity probe. This tank is known to have a hole in the bottom. Since the tank is at the interface of the groundwater table, the liquid level fluctuates as the groundwater table rises and falls.

\subsection{TANK WC-17; SOUTH OF BUILDING 3587, CORNER OF WHITE OAK AVE. AND FIFTH} ST.

Tank WC-17 is a 1000 gallon capacity tank constructed of stainless steel. The tank liquid level is monitored daily with a Robertshaw Inven-Tel 185 model conductivity probe. This tank is known to have a hole in the bottom. Since the tank is at the interface of the groundwater table, the liquid level fluctuates as the groundwater table rises and falls. 


\subsection{TANK 7560; EAST OF BUILDING 7500, MELTON VALLEY}

Tank 7560 is a 1000 gallon capacity tank constructed of stainless steel. The tank has remained empty throughout FY 1996.

\subsection{TANK 7562; EAST OF BUILDING 7500, MELTON VALLEY}

Tank 7562 is a 12,000 gallon capacity tank constructed of stainless steel. The tank is empty, and the pipelined are isolated.

\subsection{TANK T-30; SOUTH OF BUILDING 4507, UNDERGROUND IN CONCRETE PIT}

Tank T-30 is a 825 gallon capacity tank constructed of stainless steel. In August 1996, the tank and vault were filled with a low permeable grout. There is no requirement for liquid level measurement for this tank.

\subsection{TANK W-19; SOUTH OF SOUTH TANK FARM, NORTH OF BUILDING 3517}

Tank W-19 is a 2250 gallon capacity tank constructed of stainless steel. The tank has remained empty. There is no liquid level instrumentation mounted on this tank.

\subsection{TANK W-20; SOUTH OF SOUTH TANKS FARM; NORTH OF BUILDING 3517}

Tank W-20 is a 2250 gallon capacity tank constructed of stainless steel. The tank has remained empty. There is no liquid level instrumentation mounted on this tank.

\subsection{TANK 3001-B; SOUTH OF BUILDING 3001}

Tank 3001-B was removed in 1995. There is no need to monitor the liquid level.

\subsection{TANK 3003-A; SOUTH OF BUILDING 3003}

Tank 3003-A is a 16,000 gallon tank constructed of concrete. The liquid level has remained unchanged. There is no liquid level instrumentation connected to this tank.

\subsection{TANK 3004-B; EAST OF BUILDING 3008; UNDERGROUND, UNDERNEATH LANDSCAPE ROCKS ON PUBLIC ACCESS WALK TO GRAPHITE REACTOR}

Tank 3004-B was removed in 1995. There is no need to monitor the liquid level. 


$$
\text { B - } 9
$$

\subsection{TANK 3013; EAST OF BUILDING 3017, SOUTH OF BUILDING 3013}

Tank 3013 is a 400 gallon capacity tank constructed of stainless steel. The tank was isolated and filled with a low permeable grout in 1995 . There is no need to monitor the liquid level.

\subsection{TANK 7503-A; NORTHWEST OF BUILDING 7503, MELTON VALLEY}

Tank 7503-A is a 11,000 gallon capacity tank constructed of stainless steel. The tank has remained empty. There is no liquid level instrumentation connected to this tank.

\subsection{TANK H-209; SOUTHWEST OF BUILDING 3517, NEXT TO WHITE OAK AVE.}

Tank H-209 is a 2500 gallon capacity tank constructed of carbon steel. In 1996, the tank was isolated and filled with a low permeable grout. There is no need to monitor the liquid level. 


\section{DISTRIBUTION}

1. L. V. Asplund

2. T. W. Burwinkle

3. R. L. Chadwick

4. T. J. Cofer

5. M. D. Easten

6-8. S. A. Herron

9. S. L. Laman

10. J. R. Lyons II

11. D. M. Matteo

12. S. D. Nolan

13. P. T. Owen

14. P. A. Schrandt

15. A. Smith

16. M. L. Whitehead

17. K. L. Wilson

18. H. D. Wooten

19. Central Research Library

20. ER Document Management Center-RC

21. M. Goldberg, CDM Federal Programs Corporation, 800 Oak Ridge Turnpike, Suite 500, Oak Ridge, TN 37830

22. W. Rideout, The S.M. Stoller Corporation, 1060 Commerce Park Drive, Oak Ridge, TN 37830 